This is the accepted version of 'Umar, Tariq (2020) Making future floating cities sustainable : a way forward. Proceedings of the Institution of Civil Engineers - Urban Design and Planning, ISSN (print) 1755-0793'

The version of record can be accessed at https://doi.org/10.1680/jurdp.19.00015 


\title{
Making Future Floating Cities Sustainable: A Way Forward
}

\begin{abstract}
:
It is expected that by 2030, five billion of the earth's population will live in cities. This growth in urbanization results in significant challenges pertaining to environmental and social sustainability. Most of the cities are located near coastal areas and thus under the threat of sea rise. This article explores the floating sustainable cities with the key sustainable factors as an alternative to meet the future urbanization requirement. The purpose of this paper was to find the key sustainability factors and then explore the solutions to achieve them in the floating sustainable cities. A mixed research strategy using qualitative and quantitative approaches was adopted to achieve the aims of this research. The key sustainability factors were derived from the existing literature through a systematic review approach and then ranked using a questionnaire administrated among selected respondents. The top-ranked factors that include energy, water, food, waste, mobility, and habitat regeneration were considered and were further explored using a systematic review method. The review suggests that there are different arrangements and techniques available to meet the future sustainable floating cities requirement. The discussion reveals that the concept of floating cities is at its initial stage and has the potential for multidisciplinary research.
\end{abstract}

Key Words: Sustainability, Town \& city planning, Buildings, structures \& design.

\section{Introduction:}

It is a well-accepted fact that the rapid increase of the human population puts pressure on the earth's resources. Kibert (2016) estimated that if all 7.3 billion of Earth's people consumed at the same rate as the average American, it would take six planets to support them. At the beginning of the $20^{\text {th }}$ century, approximately 200 million $(12.5 \%)$ peoples were living in the cities (Townsend, 2013). The number of peoples living in cities had sharply increased in the last century, which reached $30 \%$ and $55 \%$ of the total earth population in 1950 and 2018 respectively. It is further expected that by 2030, five billion or half of the earth population will live in cities. It is further projected that by $2050,68 \%$ of the total population on the earth will be 
living in urban areas (WUP, 2018). This growth in urbanization results in significant challenges pertaining to environmental and social sustainability (OECD, 2012). Bibri and Krogstie (2017) noted that the form of contemporary cities has been viewed as a source of environmental and social problems. Cities consume about $70 \%$ of the world's resources and hence are major consumers of energy resources and significant contributors to greenhouse gas (GHG) emissions due to the density of urban population and the intensity of related economic and social activities, in addition to the inefficiency of the built environment. Globally, cities generate $70 \%$ of the total waste. The United Nations report indicates that $90 \%$ of urban dwellers have been breathing unsafe air, resulting in 4.2 million deaths due to ambient air pollution. It is estimated that more than half of the global urban population were exposed to air pollution levels at least 2.5 times higher than the safety standard. Currently, many small countries are in real need of additional sovereign territory for which they even build on rotting landfills and install various kinds of expensive artificial islands. A better solution for this as proposed by Bolonkin (2011) can be the employment of floating cities. Similarly, Lin et al. (2019) also viewed floating cities as a viable response to the rising sea level. Such cities in the first instance can be built near the coastal areas and if successful, the net of floating cities can be expended the large sea. While this is not an easy option, but can be a possible solution that needs to be explored and understood. Considering all the challenges associated with the current urbanizations, it is important that efficient urban planning and management practices are in place to deal with the challenges brought by urbanization. There needs to be a future in which cities provide opportunities for all, with access to basic services, energy, housing, transportation, and essential items for life. Considering the huge scope of urbanization and the challenges associated, "Sustainable Cities and Communities" was recognized as one of the Goals which the United Nations have set to achieve by 2030 (UNSDGs, 2015; Umar et al., 2020-a). The targets associated with this goal emphasize the safe and affordable housing, accessible and sustainable transport, sustainable urbanization, reducing water-related disasters, safeguard the world's cultural and natural heritage, reduce the adverse per capita environmental impact of cities, increase green and public spaces, strengthening national and regional development planning, Substantially increase the number of cities and human settlements, and building sustainable and resilient buildings utilizing local materials.

The sea level in different places on the earth is raising which is making some of the cities to be below the sea level. Apart from this, the cities near the sea are becoming more crowded with 
more traffic and insufficient environmental facilities. The concept of floating cities can, therefore, be a good solution for human settlement not only to tackle the issues arising from climate change but also to deal with the shortage of land. Oceans are therefore can be classified as the last option for human settlement and survival on the earth (Kirimtat et al., 2020). Irrespective of the cities whether, it is on land or oceans it should be smart, sustainable and should achieve several themes including smart people, smart economy, smart governance, smart mobility, smart environment, and smart living (Kirimtat et al., 2020). Apart from an immediate solution, floating cities can be a good lab to smart cities that can lead to a new form of human settlement. This article aims to explore the concept of future floating cities so that the current and future urbanizations requirement could be met. Both qualitative and quantitative research approaches considering systematic review and questionnaire survey methods were adopted to achieve the aims and objectives of this paper. In the first phase of the research, a qualitative approach using the systematic review method was adopted to identify the key sustainability factors for a floating city. In the second stage of the research, a quantitative research approach was deployed in which a structured questionnaire was used to rank the sustainability factors identified in the first phase of the research. In the last stage of the research, a qualitative strategy using a systematic review was used to find the solution that how the sustainability factors identified and ranked in phases one and two of the research can be achieved in a floating city. The key sustainability factors which this article aims to explore include energy, water, food, waste, mobility, and habitat regeneration.

The next briefly explain the key challenges and threats which our cities are facing.

\section{Literature Review (State of the World):}

The expansion of the cities to accommodate the rapidly increasing population is the main issue of today's urbanization (Miles, 2019). Using underground spaces is one of the solutions however several challenges exist in such solutions (Broere, 2016; Zhou and Zhao, 2016). Similarly, coastal community and place management has been considered in several research studies to understand the place uses, however, no or very little attention is given to the concept of floating cities and its sustainability (Piyapong et al., 2019). Similarly, the sustainable prosperity of cities and countries is possible through place management and development (Mariutti, 2017). Presently, about $40 \%$ of the world's population lives within 100 kilometers of the coastal area 
(Columbia University, 2019). The expansion of these coastal areas to effectively serve the population growth with appropriate and sustainable place management thus becomes more important. As population density and economic activity in the coastal area increases, pressures on coastal ecosystems increase. Using underground spaces near coastal areas have more challenges and impact on the eutrophic coastal environment (Nakayama et al., 2007). Coastal cities struggle to cope with rapid population growth; many simply pour sand into the ocean to create new land (NLBS, 2017). This appears to be a temporary solution as due to global warming the sea level is gradually increasing. For instance, during 1901-2010, the sea level rose by $0.19 \mathrm{~m}$ (IPCC, 2013). Thus due to climate change, cities located near coastal areas are increasingly at risk of flooding. For instance in Bangkok, the ground on which some parts of the city stand is sinking by around two centimeters every year. Similarly, Jakarta has a population of 10 million people is sinking faster than any other city in the world (Erkens et al., 2015). United Nations report predicts that $90 \%$ of the world's biggest cities will be exposed to rising sea levels (UNHabitat, 2019). Considering these facts it is necessary that the cities must be build knowing that they will be on the frontlines of climate-related risks including risk from rising sea levels to storms.

In this regard, the concept of sustainable floating cities which has been recently discussed in the United Nations high-level round table has attracted the attention of peoples, countries, and organizations around the world (UN-SFC, 2019). The ocean covers two thirds (66.66\%) of the earth. It is a vast resource that can help solve the complex challenges coastal cities face. While considering the pressure of current cities, Bolonkin (2010) proposed the floating cities on the large ice platform that needs to be protected by air-film (bottom and sides) and a conventional insulating cover (top). Although, he focused on the stabilities of the ice platform on which the floating cities to be built, however, he did not cover the remaining factor related to the sustainability of such cities. Similarly, James (2012) considered the large size of the cruise ship as a floating city and discussed some sustainability and safety factors that include energy efficiency. Although energy is one of the main sustainability factors, it is not only related to energy efficiency but also related to clean and sustainable production of energy. This article, therefore, discusses the historical background of floating cities and focuses on the main solutions to make such cities sustainable considering Energy, Water, Food, Waste Systems, Mobility, and Habitat Regeneration as main factors. Of course, floating sustainable cities are not the solution 
for climate change, but if climate actions as required by Goal 13 on the UN SDGs are not taken the floating cities can be an alternative option to provide the solution for human settlement. Similarly, even in the current situation, floating cities can be an alternative solution to reduce the burden on the existing cities and if properly managed, it can lower the speed of climate change as such cities will aim to reduce the use of natural resources and will thus result in a reduced footprint. Apart from this, the sustainability factors that are applicable to floating cities can also be adopted in current cities which can be helpful to slow the rate of climate change.

While the sustainability factors for floating cities are important and this paper is exploring the ways how to achieve these key sustainability factors, there is another important factor that is related to different stakeholders of these cities. This factor is normally known as the human factor and is well recognized by place management practitioners and researchers. For instance, the additional three factors for place-making tactics derived from the existing literature by Mengi and Guaralda (2020) include the human factor. The institutional factors and the art and design factor were part of the factors derived in this study. The stakeholders' perception and engagement in such cites will, therefore, be important so that the floating cities get the traction as a mainstream option. The floating cities are a new concept which still needs to be materialized; however, it is important to explore that how different communities of place-stakeholders might engage with them, and what would be the role of place managers in facilitating this process. While such human factors are outside the scope of this paper, however, since these aspects are so important; they are discussed in the paragraph.

One of the important factors that will significantly contribute to the success of the floating cities is the place marketing and place branding. The involvement of the key stakeholders in the place marketing and branding that may include the (1) visitors; (2) residents; and (3) business will, therefore, be significantly important (Kotler et al., 1993; Beckmann and Zenker, 2012). Other studies, however, argue that the residents' quality of life and their satisfaction with their city of residence should be the ultimate aim of place management (Insch and Florek, 2008; Zenker and Rütter, 2014). Similarly, Insch (2010) viewed the residents' satisfaction as crucial for the place management and noted that this element is mostly overlooked. The residents (citizen) satisfaction index model developed by Zenker et al. (2013) considered the main four items including i) Urbanity and Diversity, ii) Nature and Recreation, iii) Job Chances and iv) Cost 
Efficiency. Since the floating cities are projected to be in the coastal areas where temperature and humidity remain high, thus such high temperatures and humidity will be affecting the residents' satisfaction. A study related to heat stress conducted by Umar and Egbu (2020) reported that the temperature in the Arabian Gulf region reaches to $50^{\circ} \mathrm{C}$ in summer. They further reported that the summer season in this region is comparatively longer and could be more than 6 months. Such high temperature affects human performance and therefore results in many accidents in workplaces (Umar, 2017-a). One of the key challenges for the future floating cities will, therefore, be the residents' satisfaction and wellbeing. The residents' satisfaction in such floating cities can be truly gauged when there is a small scale project, people live there for a certain time and then provide feedback on their living experience. Such projects, however, would not only be costly but also risky in a situation when the residents provide negative feedback.

Similarly, the basic assumption discussed by Boisen et al. (2018) that promotion, marketing, and branding of cities can attract the residents, businesses, and visitors and thus may work for the floating cities, however, it will be quite challenging for the place managers. At first instance, the place managers would struggle to convince the private sector to invest in floating cities, thus such cities are expected to be highly dependent on funding from the government. Secondly, the concept of the floating cities is totally new, thus everyone including the potential residents, investors, and visitors will be reluctant at a different level to live, invest, and visit these cities. Overall, the social aspects of the sustainability pillars will have a great influence on the success of such cities, and therefore it needs to be understood first. The scope of this aspect, however, is quite large that it cannot be covered in a single paper. Since this paper focuses on some other sustainability factors mentioned above, the investigation of human or social factors is therefore not considered in this paper. It is, however, worth mentioning that despite different challenges associated with the floating cities, there are many projects around the world related to the floating cities. For instance, the Seasteading Institute is aiming to open its first floating city in 2022 which will offer homes to 300 people (Seasteading Institute, 2020). Although floating cities are getting closer, however, to get them faster, all the key stakeholders need to be on the same page. This paper will, therefore, be helpful in understating the key elements of floating cities and their accomplishment in a sustainable manner.

The research methodology used in this work is explained in the next section. 


\section{Research Methodology:}

Considering different research approaches, research methods can be classified as qualitative or quantitative (Umar and Egbu, 2018-b). Quantitative research stresses quantification in data collection and examination. It takes a deducible way to the connection among theory and research and stress are kept on the confirmation of theories. The quantitative research method integrates the norms and practices of the natural scientific model and positivism. It views the social phenomenon as an outer objective truth (Cooper et al., 2006; Bryman, 2016). A systematic literature review can be classified as quantitative or qualitative as it identifies, selects, and critically appraises research in order to answer a clearly formulated question (Gough et al., 2017; Martins et al., 2019). The aim of this research was to explore the floating cities from a historical perspective and if these cities are to be adopted to meet the requirement of increasing population and urbanization, how they could be sustainable. The article further aimed to examine the possible solutions to meet the most essential requirement of floating cities in a sustainable way. A mixed research reproach using both qualitative and quantitative was considered to be best suited to accomplish the aims and objectives of this research. The research was started using a qualitative approach to identify the key sustainability factors associated with the floating and coastal cities. This was done through a systematic review using specific keywords in reputed search engines that include Web of Science, Scopus, Science Direct, and ProQuest. The search period was considered from January 2010 to June 2019, covering a period of 10 years. The Preferred Reporting Items for Systematic Reviews and Meta-Analyses (PRISMA) guidelines as reported by Umar et al. (2019-a) were followed in this systematic review.

After finding the key sustainability factors from the existing literature associated with the floating and coastal cities, a quantitative approach was adopted to rank the essential features (factors) that play a significant role to make the cities sustainable. A similar approach was also adopted by Lak et al. (2019) in their research related to the spaces under highway and bridges. A questionnaire was then developed considering the features (factors) mentioned in section 4.1 and was sent to the selected respondents. The ultimate aim of this questionnaire was to establish the ranking of the sustainability factors considering the view of the academic and industrial respondents specialized in sustainable cities. The systematic literature review resulted in a large number of factors that can be not considered in a single paper. Therefore the expert view helped 
to set a criterion and considered the top raked factors for further investigation. The respondents who have experience and expertise in sustainable cities were selected from academia and industry. The literature review suggests that university professors and lecturers were considered as respondents in many studies. For instance, Dawson in his research investigated the perspective of university teachers on climate change considering a sample of 39 teachers (Dawson, 2012). Similarly, another study which aimed to investigate the challenges to renewable energy considered the early-stage researchers $(\mathrm{PhDs})$ and professors as respondents. This study also used the quantitative approach and the number of respondents was 122 , however, the percentage of professors was only $18 \%$ (Zyadin et al., 2014). A recent study on the challenges associated with renewable energy in the Arabian Gulf region also considered the University lecturers and professors from five different countries as the key respondents (Umar et al., 2020-b).

The universities and college professors or lecturers were considered to be more suitable respondents based on academic integrity or academic freedom and based on their interest in sustainable development. A mainstay of academic life for professors is professional or academic autonomy, often called simply academic freedom (Aberbach and Christensen, 2017). Academic freedom may be defined as the freedom to conduct research, teach, speak, and publish, subject to norms and standards of scholarly inquiry, without interference or penalty, wherever the search for truth and understanding may lead (GCUP, 2005). The unique role of the professors and teachers in striving to promote sustainable development was well reported by Ocetkiewicz et al. (2017). In their research on renewable energy in education for sustainable development, they emphasized the social role of the teachers which could lead the process of dynamic social change and increase the adaptability of sustainability and renewable energy. The professors and teachers are not only the translators but they interpret and guide in the world of values (Alexander, 2006). The Mathiesen et al., (2015) quoting the "Coherent Energy and Environmental System Analyses" project which was held in Denmark, noted that this project involved more than 20 researchers from seven different universities and research institutions.

Similarly, there are many studies related to the general themes of sustainability in which the views of the respondents from the relevant industries were considered significant and thus industrial respondents were the main part of the data collection. For instance, a study on the assessment of social sustainability conducted by Ahmadi et al. (2017) used 38 Iranian 
manufacturing sector practitioners. Another study that explored the methods for the improvement of corporate sustainable development collected data from 57 respondents via face-to-face interviews which include both industrial practitioners and academicians (Shi et al., 2015). A study entitled integration and organizational change towards sustainability carried out by Sroufe (2017) in which the author conducted interviews with sustainability professionals from 17 different organizations. Similarly, Armindo et al. (2019) in their research study on the importance of sustainability dimensions in the Portuguese industries used 211 industrial practitioners. Overall, the above discussion reveals that participants from industrial sectors are considered as a useful source of information for research studies related to sustainability.

An internet search was deployed to find suitable respondents both from academia and industry using the key terms such as "lecturer/professor of sustainability", "expert/architect/engineer in sustainable cities", "lecturer/professor in urban planning" and expert/architect/engineer in urban planning". Relevant information related to the potential respondents that include qualification, expertise, research interest experience, and email was obtained from their organization/personal web page. A screening criterion was employed for the inclusion of the respondents in the study. This criterion was based on educational qualifications, experience, expertise, and research interest. For respondents from academic backgrounds, the academic qualification was set as a Ph.D. in any related field of engineering, sustainability, urban planning, and architecture. The minimum rank for the academic respondents was set as associate professor or senior lecturer with a total experience of not less than 10 years with at least two years in the current rank. The academic respondents were required to have research interest relevant to the theme of the current research i.e. floating cities, coastal cities, sustainable cities, or sustainable urban planning. Similarly, the criteria set for the industrial respondents include a minimum academic qualification Bachelor's degree in any relevant field of engineering, technology, architecture, sustainability, town, and regional planning or urban planning. The respondents from the academic should have at least 15 years of total experience and their expertise need to be aligned with the theme of this research.

The questionnaire developed on the data collected at the first stage of the research was consisting of a total of seventeen parts. In the first part of the questionnaire, the purpose of the study, confidentiality policy, and consent to participation in the study was provided. The second part of 
the questionnaire was related to the personal information was the respondents, in which gender, academic qualification, age, experience, research interests, based location, and specialization of the respondents were asked. Parts three to thirteen of the questionnaire was related to the features (factors) selected for the sustainable floating cities that include Design and Materials, Land Management, Energy, Human Comfort (Temperature and Humidity), Food, Mobility, Water Management, Waste Management, Habitat Regeneration, and Risk Management. Each of these items was supported through a number of sub-items in which respondents were asked to rate on a Likert scale of 1 (strongly disagree) to 5 (strongly agree). Such an approach to rank factors in a research study is adopted by many researchers (Umar et al., 2019-b). In the second last part of the questionnaire respondents was asked to rate the adaptation of the floating cities as a solution for the future urbanization on a Likert scale of 1 (strongly disagree) to 5 (strongly agree). In the last section of the questionnaire, the respondents were given an opportunity to provide additional comments which they feel important with this study. Descriptive analyses were conducted using SPSS (23.0) to find the overall ranking of different factors. Factors which achieved the mean score of 4 and above were considered for further exploration in this study.

At the final stage of the research, a systematic literature review was adopted as a research strategy to explore how to meet the selected features requirement of a floating sustainable city. The stages corresponded to the definition of the publication periods considered, the keywords, the database, and the criteria of inclusion and exclusion of the articles. After this, relevant information was extracted, the information synthesized, and, finally, the creation of this article. A similar methodology was also adopted by Beza and Hernández-Garcia (2018) in their research related to the place-making and sustainability citizenship relationship. To ensure that a systematic review process is adopted in this study, the research method for the review was guided by Preferred Reporting Items for Systematic Reviews and Meta-Analyses (PRISMA). The PRISMA guidelines required to follow a four steps process to include the final of studies in the systematic review and meta-analysis (Moher et al., 2009). The details of all the parameters including inclusion and exclusion criteria, the period of search, keywords, and databases used in this review along with the results are given in appendix II.

The next section outlines the results and discussion of the study. 


\section{Results and Discussion:}

As explained in the research methodology section, the study was carried out using different approaches, thus the results of each approach are outlined in separate sections. The first section explains the results of the first phase of the systematic literature review which aimed to identify the main factors associated with the floating and coastal cities.

\subsection{Results and Discussion of the Systematic Review (Stage I):}

A total of 87 research articles were downloaded from the main four selected databases that include Web of Science, PRO QUEST, SCOPUS, and Science Direct. After the screening criteria mentioned in the appendix I was applied, a total of 44 articles were excluded, thus the number of research articles left behind was 43 . These articles were thoroughly reviewed for the extraction of sustainability factors. The factors found in each article were coded so that in the end, duplicate factors can be easily removed. Two criteria were adopted for the ranking of the factors extracted from the papers. 50\% of the weightage was given to the journals impact factor in which the papers were published from where the factor was extracted and $25 \%$ weightage was given to citations of the papers from which the factors were extracted. The remaining $25 \%$ weightage was given to the importance of the factor that was given in the paper. For instance, if the factor was given the top importance in the paper, it was given a score of 10 . The score reduces if the importance of the factor reduces in the paper. For instance, the Design and Materials are ranked on the top as this factor achieved on the highest score based on the criteria adopted using equation 1 .

Ranking of Factor = $\quad \mathrm{R}_{\mathrm{f}}=$ Sum of Impact Factors (SIF)x 50\% + Sum of Citaitons(SoC) $x 25 \%+$ Sum of Impportance Factor (SoIF) x 25\% ................Equation 1.

Sum of Impact Factors (SIF) for Design and Materials (factor) = $1.50+0.50+1.20+1.78+1.12+1.78+1.10+0.89+1.71+0.98=\mathbf{1 2 . 5 6}$

Sum of Citations $(\mathrm{SoC})$ for Design and Materials $($ factor $)=2+10+15+6+8+9+21+5+16+8=\mathbf{1 0 0}$

Sum of Importance Factor (SoIF) for Design and Materials (factor) $=10+8+7+5+2+6+8+4+3+7$ $=60$ 
$\mathrm{R}_{\mathrm{f}}($ Design and Materials $)=12.56 \times 0.5+100 \times 0.25+60 \times 0.25=\mathbf{4 6 . 2 8}$

After reviewing all the articles, a list of the final 10 factors as mentioned in the appendix I was produced. The total score of the top ten factors and scores of each component of these factors are shown in table 1. The top 10 ranked factors were then used to develop the structured questionnaire for which the results are presented in the next section.

\begin{tabular}{|r|l|l|c|c|c|}
\hline S.No. & Factor & $\begin{array}{l}\text { Sum of } \\
\text { Impact } \\
\text { Factors (SIF) } \\
\mathbf{x ~ 0 . 5}\end{array}$ & $\begin{array}{l}\text { Sum of } \\
\text { Citations (SoC) } \\
\mathbf{x ~ 0 . 2 5}\end{array}$ & $\begin{array}{l}\text { Sum of } \\
\text { Importance } \\
\text { Factor (SoIF) } \\
\mathbf{x ~ 0 . 2 5}\end{array}$ & $\begin{array}{l}\text { Ranking of Factor } \\
\text { (Rf) = } \\
\text { SIF+SoC+SoIF }\end{array}$ \\
\hline 1 & $\begin{array}{l}\text { Design and } \\
\text { Materials }\end{array}$ & 6.28 & 25 & 15 & 46.28 \\
\hline 2 & Land Management & 5.98 & 24 & 13 & 42.98 \\
\hline 3 & Energy & 5.71 & 20 & 10 & 35.71 \\
\hline 4 & $\begin{array}{l}\text { Human Comfort } \\
\text { (Temperature and }\end{array}$ & 5.41 & 18 & 10 & 33.41 \\
\hline 5 & & & & \\
\hline 6 & Humidity) & 5.28 & 20 & 8 & 33.28 \\
\hline 7 & Wood & 5.2 & 16 & 10 & 31.2 \\
\hline 8 & Water Management & 5.3 & 16 & 6 & 27.3 \\
\hline 9 & $\begin{array}{l}\text { Habitat } \\
\text { Regeneration }\end{array}$ & 4.8 & 18 & 4 & 26.8 \\
\hline 10 & Risk Management & 4.4 & 12 & 8 & 22.2 \\
\hline
\end{tabular}

Table 1: Ranking of Top Ten Sustainability Factors of Floating/Coastal Cities

\subsection{Results and Discussion of the Structured Questionnaire (Stage II):}

The questionnaire was electronically sent to 112 selected participants through the emails obtained from the organization or personal web pages. 61.60\% (69) participants were from academia and $38.40 \%$ (43) were from industry. The respondents were asked to complete the questionnaire in a one month time. During this period, two reminders were sent to the participants who have not completed the survey. A total of 43 respondents (38.39\%) completed the questionnaire. $28(65.11 \%)$ respondents were from academics and $15(34.88 \%)$ were from the industry side. The majority of the participants $(76.74 \%)$ were male and 10 participants were female. It was decided that in a questionnaire if more $50 \%$ of the questions were not answered will be rejected. Following this criterion, no questionnaire was rejected. In relation to the 
satisfactory response rate of the survey, the literature review provides different statistics. For instance, a study carried out by Shih and Xitao (2008) analyzed a total of 39 different papers published from 1998 to 2006 which have used the data collection tool administrated through web and paper-based. The results show that the average response rate of the web survey was $33.87 \%$ while the paper-based response rate was $44.56 \%$. Since the questionnaire used in this research was a web base and was distributed through email, thus the response rate received $(=38.39 \%)$ is considered satisfactory. The normality of the collected data was checked through the ratio between skewness, kurtosis, and standard error for age. The ratio between skewness and its standards error for age was 0.61. Similarly, the ratio between kurtosis and its standard error for age was 1.34 . Both the ratios were found to be less than \pm 1.96 , and reflect the normality of data. The correlation between age and qualification of the respondents was found to be significant at the 0.05 level ( 2 tailed). The internal reliability of all the Likert items along with the qualification, position, and region of respondents was checked by calculating Cronbach's Alpha ( $\alpha$ ) using SPSS and was found to be 0.620 .

The mean age of the participants was $46 \pm 3.2$ years. The majority of the participants $(62.79 \%)$ were in the rage of 41-54 years as shown in figure 1. This was due to the experience set during the screening criteria for the selection of the respondents. Similarly, the experience of the majority of the respondents $(55.81 \%)$ was in the rage of 10 to 20 years. The mean experience of the respondents was $17 \pm 3.4$ years. The experience of the participants is further presented in figure 2. In terms of the qualifications, all of the participants from academia were holding a Ph.D., while the majority of the participants from the industry were holding a Bachelor's degree. All the participants from the academic background mentioned their research interest in sustainable cities. The participant's expertise was divided into five main categories including Engineering, Sustainability, Urban Planning, Architecture, and Town and Regional Planning. Engineering and Architecture were the expertise of the majority of the respondents as shown in figure 3. Respondents were from different regions and were thus divided into six main categories as shown in figure 4 . The European region was on the top with 15 participants representing $34.88 \%$ of the total respondents. 


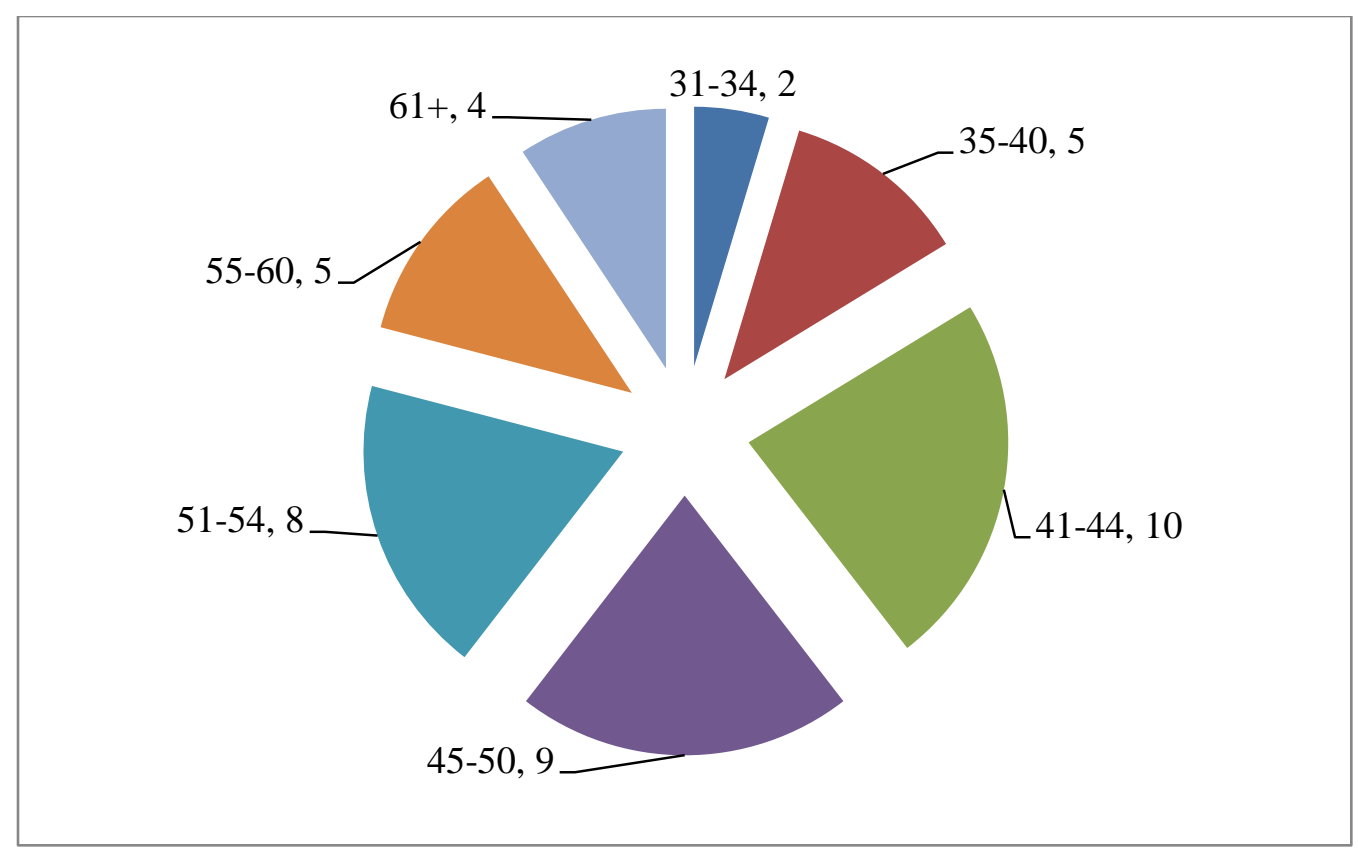

Figure 1: Age of the Participants

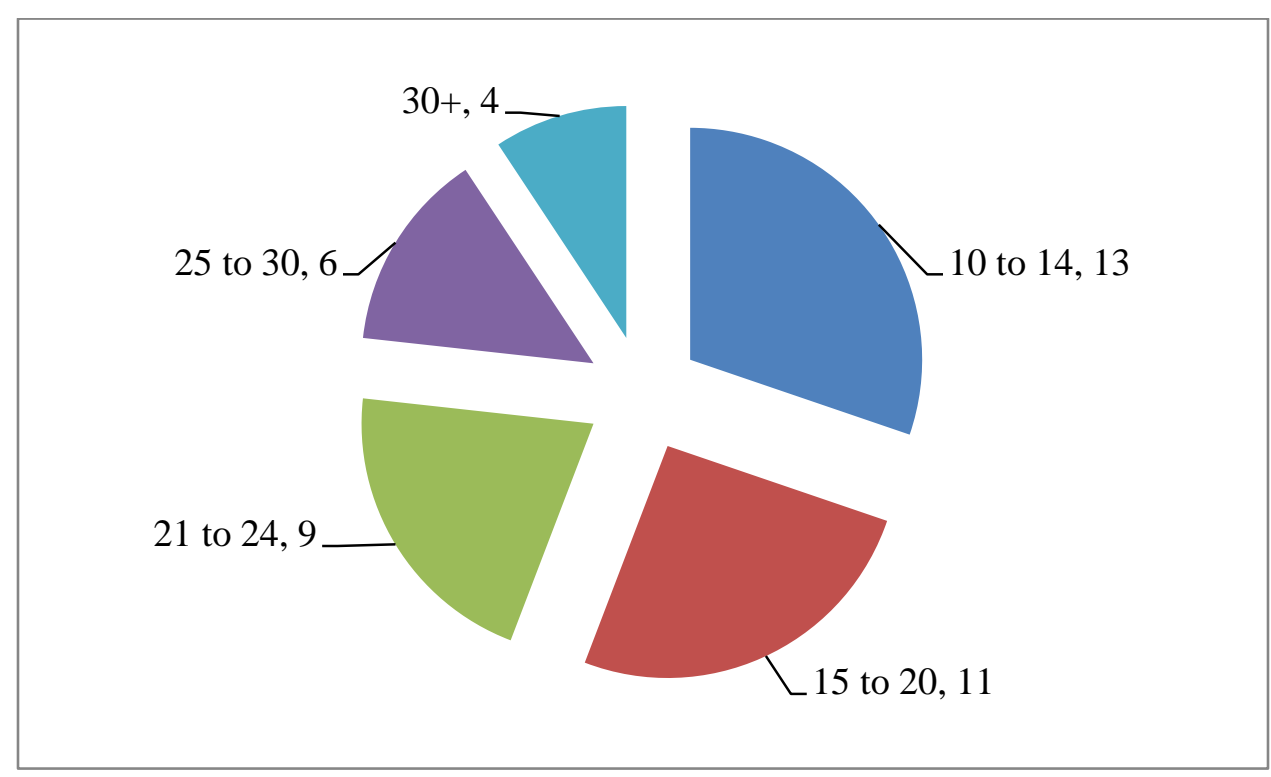

Figure 2: Experience of the Respondents 


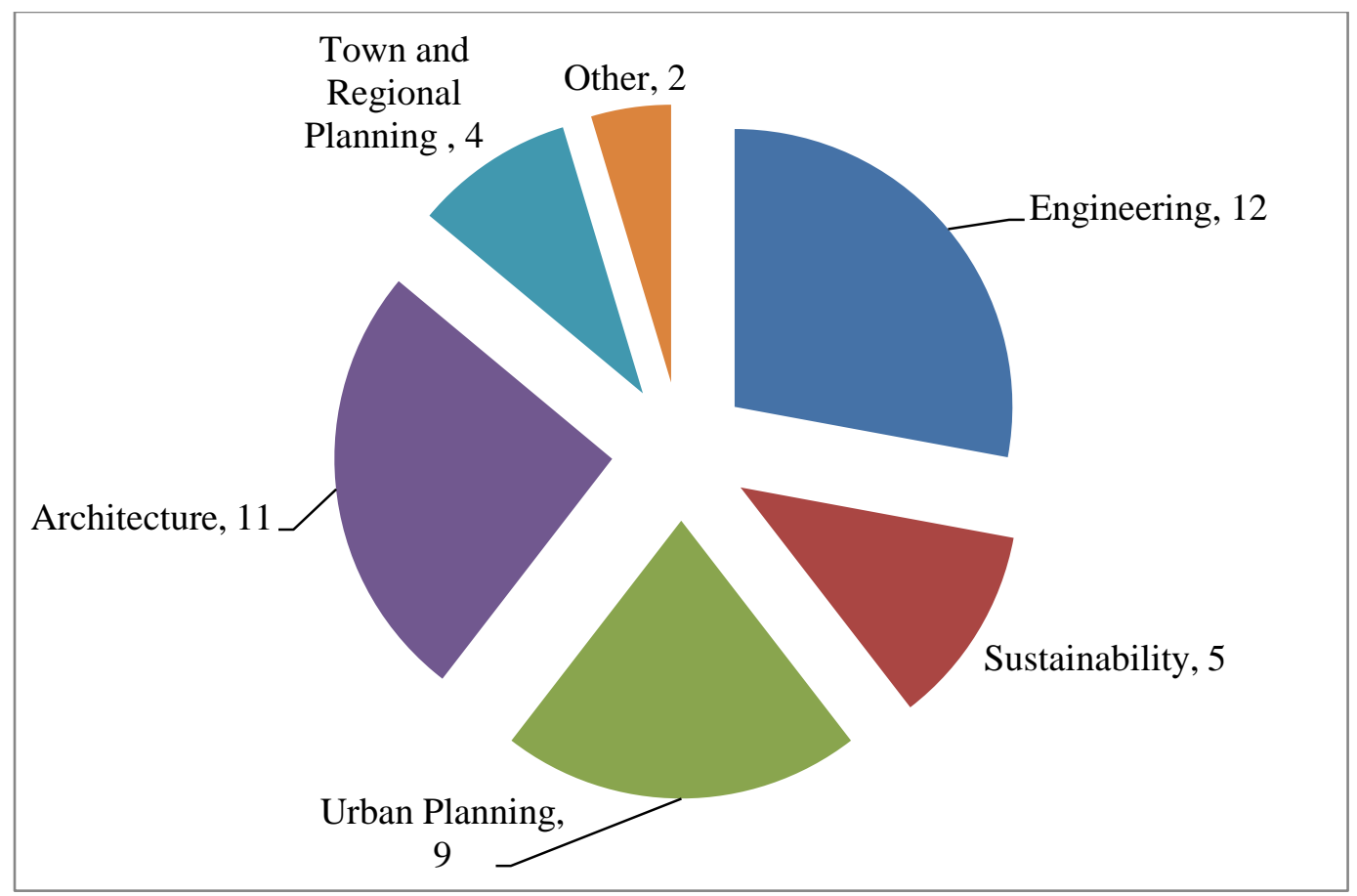

Figure 3: Expertise of the Respondents

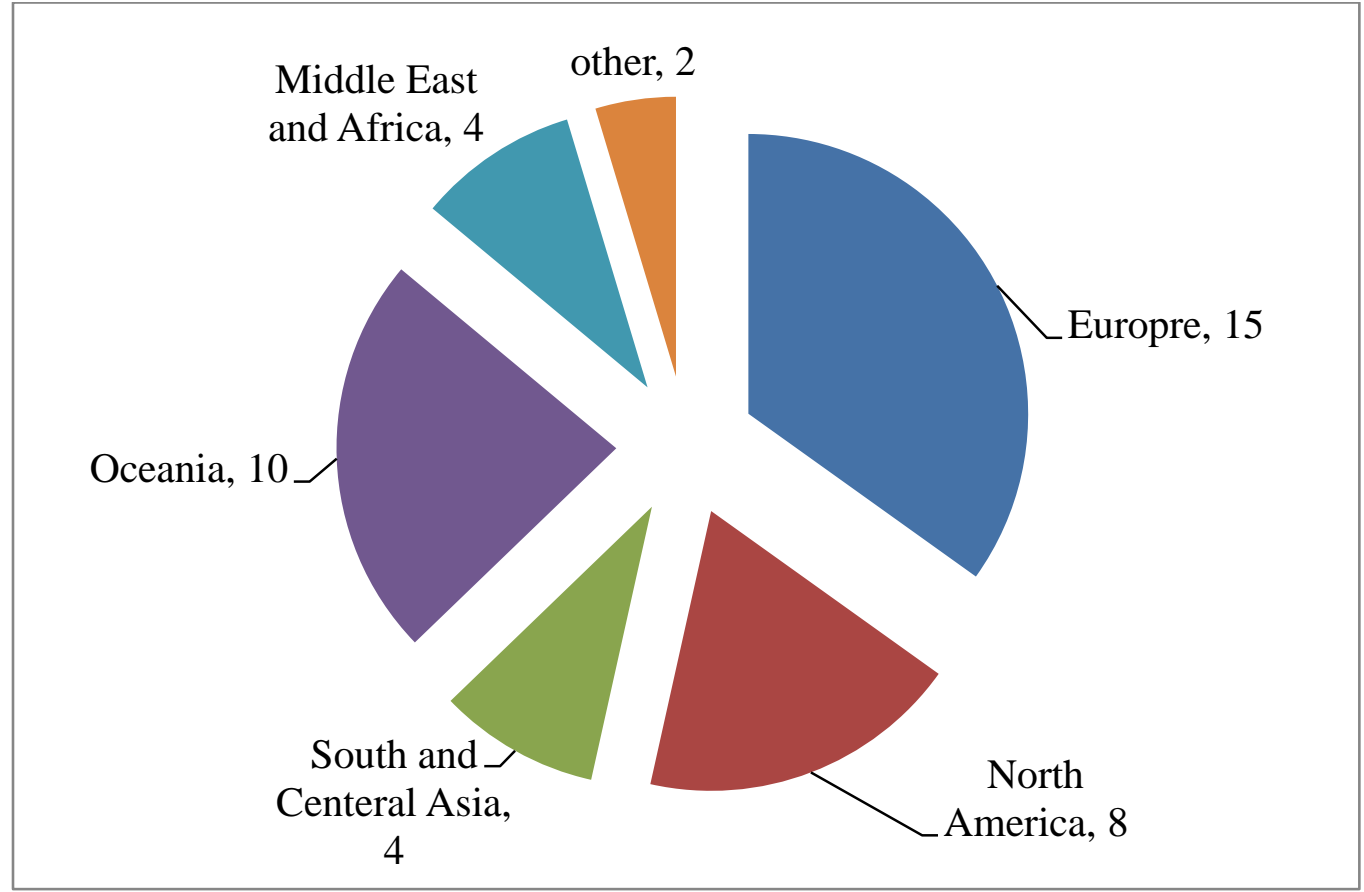

Figure 4: Participants Distribution Based on their Locations 
The mean score of all the dimensions used in the questionnaire was calculated using the SPPS software. This was done to rank the top leading factors which respondents considered as important in relation to the floating cities. While there are other statistical methods available for such raking, however as discussed in the methodology section, descriptive analysis is one of the common methods adopted by many researchers. The factors which achieved the mean score of 4 and above were ranked as shown in table 2. Although the factors which achieved the mean score of more than 2.5 can be considered as important, however, in this paper, only the factors which achieved the mean score of more than 4 were considered as it is not possible to cover all these factors in a single paper. These factors are further discussed in the later sections in more detail and with the results obtained from the systematic review (stage III). Similarly, when the respondents were asked that do they consider floating cities as one of the solutions towards global urbanizations, the majority (86.04\%) of them agreed that this (floating cities) is an important solution to meet the new cities' requirements (figure 5). Content analyses were conducted on the open end question in the past part of the questionnaire using Graneheim and Lundman (2004) guidelines. Only two participants provided some comments highlighting the historical perspective of the floating cities. This was one of the reasons to include the history of the floating cities in stage III of the research.

\begin{tabular}{|l|r|r|}
\hline Factors & \multicolumn{1}{|l|}{ Mean } & \multicolumn{1}{l|}{ Rank } \\
\hline Energy & 4.751 & 1 \\
\hline Water & 4.512 & 2 \\
\hline Food & 4.416 & 3 \\
\hline Waste & 4.314 & 4 \\
\hline Mobility & 4.21 & 5 \\
\hline $\begin{array}{l}\text { Habitat } \\
\text { Regeneration }\end{array}$ & 4.18 & 6 \\
\hline
\end{tabular}

Table 2: Ranking of sustainability Factors 


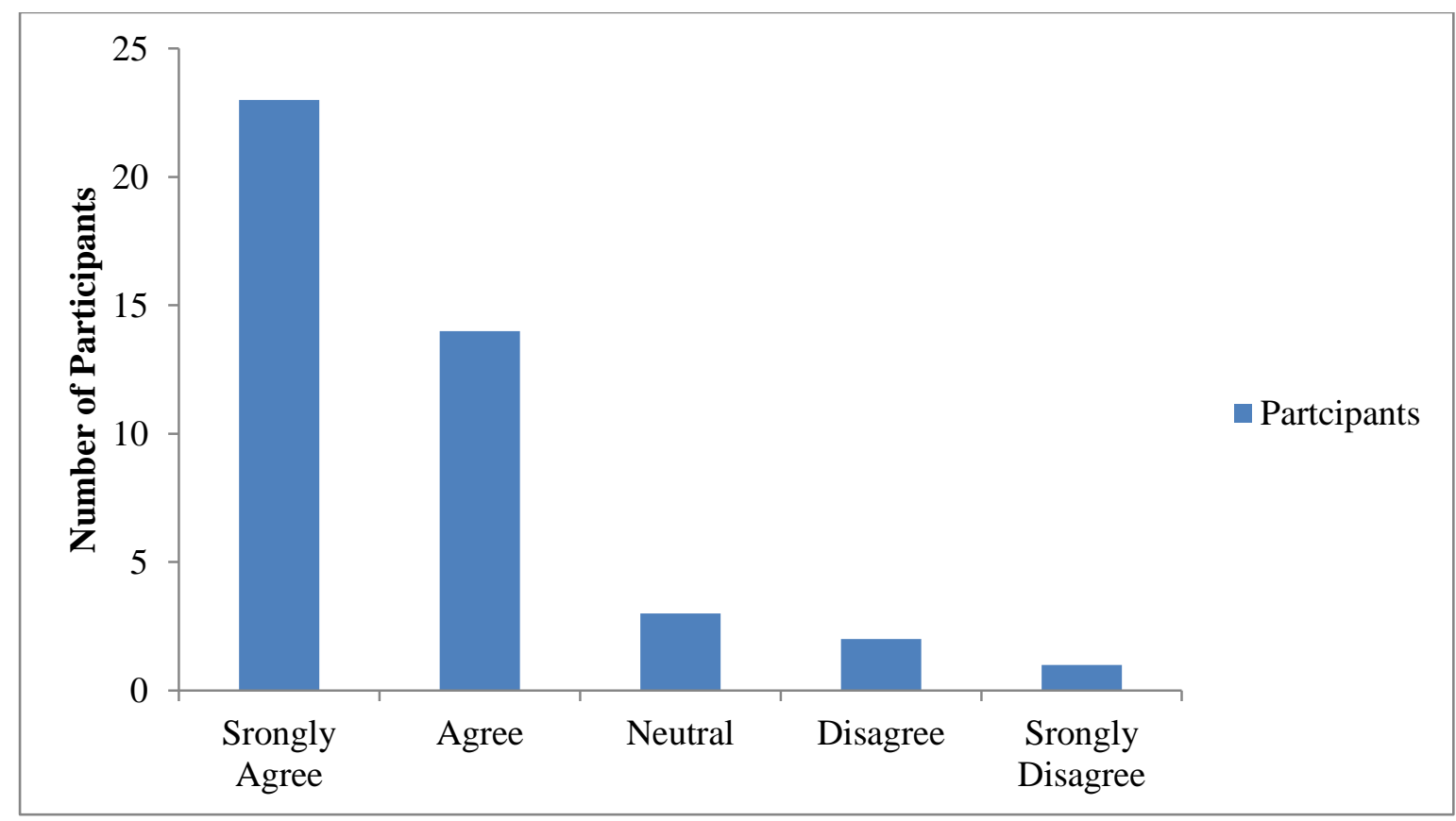

Figure 5: Participants View of the Floating Cities as a Possible Solution for Urbanization

The next section presents the results and discussion of the systematic review carried out in stage III of the research.

\subsection{Results and Discussion of the Systematic Review (Stage III):}

Considering the scope of this section, the results and discussion of stage III (systematic review) are further divided into two main sections that include (i) history of floating cities and the (ii) sustainability factors. The section related to the sustainability factors is further divided into six sub-sections.

\subsubsection{The History of Floating Cities:}

The initial search related to the history of floating cities resulted in a large number of articles and reports, however, after the screening criteria were applied, a total of 11 items were selected. While using the keywords mentioned in appendix II, a total of 171 records were identified through the database search. At the duplicate items checking stage, a total of 38 items were removed, bringing the remaining items to 133. A total of 76 items were then excluded for different reasons. The most common reason for the exclusion in this stage was that either the items were not relevant to the scope of the study or it was difficult to ascertain that the items fit the study as the items were not fully accessible. In the next stage, a total of 57 items were 
assessed for the eligibility criteria mentioned in Appendix II, and finally, a total of 11 items were selected for the final inclusion in the quantitative synthesis. The details of these items are presented in table 3 .

\begin{tabular}{|c|c|c|}
\hline Item Type & Year & Reference \\
\hline Journal Paper & 1972 & Calnek, 1972 \\
\hline Book & 1984 & Fagan, 1984 \\
\hline News Report & 2018 & BBC, 2018 \\
\hline Book & 2012 & Ferraro, 2012 \\
\hline Book & 2006 & Ciriacono, 2006 \\
\hline Web Page & 2019 & MOMA, 2019 \\
\hline Web Page & 2019 & SAM, 2019 \\
\hline Conference Paper & 1999 & Masuda et al. \\
& & (1999) \\
\hline Book Chapter & 2011 & Bolonkin (2011) \\
\hline Journal Paper & 2010 & Bolonkin (2010) \\
\hline Journal Paper & 2012 & James (2012) \\
\hline
\end{tabular}

Table 3: List of Items in Review of History of Floating Cities

The qualitative analysis of the final items suggests that the concepts of floating cities are not new, and in fact, the idea goes all the way back to the Aztecs (Fagan, 1984). When Spanish conquistadors under the command of Hernan Cortes landed in Mexico in the 16th Century, they encountered the unique indigenous empire of the Aztecs. The capital city of this vast, wealthy empire was a floating metropolis known as Tenochtitlan (Calnek, 1972). This was a vast city spread out over the lake, covering an area of $14 \mathrm{sq} . \mathrm{km}$. A three $\mathrm{km}$ long aqueduct used to bring fresh waste to the city from the surrounding hills. Similarly, food was grown in a series of floating gardens around the city which feed around 400,000 peoples living in the city. Today the area is known as Mexico City (BBC, 2018). The Venice city can be one of the examples of floating cities, which is one of the most extraordinary cities in the world was built on 118 islands in the middle of the Venetian Lagoon at the head of the Adriatic Sea in Northern Italy (Ferraro, 2012). The history reflects that when the new settlers arrived on the islands around 402 A.D., they were faced with the need for more space and a stronger foundation to live on. They had to find ways to strengthen the islands, drain them, enlarge them, and protect the fragile environment. So, they dug hundreds of canals and shored up the banks with wood pilings. They also used similar wood pilings as foundations for their buildings. The settlers pounded thousands 
of wooden piles into the mud, so close together that they were touching. Then, they cut off the tops and created solid platforms for the foundations of their homes. Because the wood was underwater, it didn't rot. It is hard to believe, but there are many buildings in Venice today that are still standing on 1,000 year old piles of wood (Ciriacono, 2006). In 1960, Architect Buckminster Fuller also planned a floating city located in Yomiuriland, Japan (MOMA, 2019). This bold design was to form a tetrahedron (a four-sided triangular solid), with each edge measuring two $3.21 \mathrm{~km}$. The buoyant metropolis was designed to accommodate one million citizens in 300,000 apartment units, and it even includes a huge interior harbor. Recently, in a canal in North Amsterdam, a new neighborhood is taking shape-out on the water. The goal of this project is to "make a really circular, resilient, floating neighborhood". This project consists of a total of 30 water plots, on which 46 unique water dwellings are being built for more than 100 residents. The first seven houses are now in place (SAM, 2019). In fact, it is also better to mention here that the history of the floating cities has already attracted the attention of the academic researcher as some of the research papers founded during the search process also explore the scientific methods for the history of the floating cities (Masuda et al., 1999).

Overall, the above discussion reveals that the concept of floating cities is not new, however, to make such cities more sustainable some of the key factors that need to be considered. These factors are discussed in the next section.

\subsubsection{Sustainability Factors:}

It is important that the floating cities to be designed in a way that maximum sustainability could be achieved (Suzuki, 2005). The area selected for such cities should be easily accessible and should be in protected water (Nakajima and Umeyama, 2009). Materials for construction should be given a priority and only materials that are locally available and could reduce carbon footprint may be used. In this case, fast-growing bamboo which has six times the tensile strength of steel, a negative carbon footprint, and can be grown on the floating cities themselves could be one of the best materials to be used extensively (Lakkad and Patel,1981; Kaminski et al., 2016). Similarly, reduction in the waste during the construction process will significantly increase the sustainability factors (Umar et al., 2019-c). Ideally, floating Cities can be prefabricated onshore and towed to their final site, reducing construction costs (El-Shihy and Ezquiaga, 2019). During the systematic review search, a total of 582 items were identified using selected databases. After 
the duplicates items were removed, the items were reduced to 501. After applying further screening, 271 items were found to be eligible for further screening. At the final screening stage, a total of 189 were excluded and thus the final items considered for the qualitative synthesis stood at 72 as mentioned in Appendix III. Based on the information gathered from these 72 items, the top-ranked sustainability factors are discussed in the next sections. 


\subsubsection{Energy:}

In relation to energy, two factors will play an important role. One is clean energy production and the other is energy efficiency (Rassia and Pardalos, 2014; Nagpal et al., 2019). Currently, the way the energy is produced and consumed is not sustainable which creates several environmental and global issues (Umar and Egbu, 2019). There are many renewable energy resources exist on the earth that commonly includes solar, wind, geothermal and biomass, the progress towards utilizing these resources is slow (Wang et al., 2017; Umar and Wamuziri, 2016; Umar, 2018-a; Lund and Boyd, 2016; Umar, 2018-b). Generally, solar panels required a large area to produce a good amount of clean energy; however, such panels can be installed on the rooftop and even in some suitable offshore locations (Umar, 2017-b; Kumar et al., 2015). Chel and Kaushik (2018) highlighted the four main aspects of energy efficiency in a building. These aspects include (i) the nearly zero energy passive building design before actual construction, (ii) secondly the usage of low energy building materials during its construction, (iii) thirdly use of energy-efficient equipment for low operational energy requirement and (iv) lastly integration of renewable energy technologies for various applications. Similarly, the integration of renewable energy into the power grid poses significant technical challenges including power quality (Liang, 2017). Such issues, however, would not have an implication of the energy production and consumption in the floating cities as in these cities the production of the energy will be only from the renewable sources and the consumption should be reduced to a possible minimum level. Considering the latest energy efficiency techniques, the daily energy requirement per capita in a floating city could be $31 \mathrm{kWh}$ as shown in figure 6 (IEA, 2016; Visual Capitalist, 2016). Oceanix was part of the proposals for sustainable cities that have been recently discussed in the United Nations. It was proposed that the entire energy requirement per capita in the floating cities will be met from clean and renewable energy resources that include solar, wind, ocean, and experimental as shown in figure 7 (OCEANIX, 2019). Oceans itself has a potential of renewable energy in the form of waves and tidal current energy which can be easily utilized in the floating cities (Uihlein and Magagna, 2016). Overall, the sustainable floating cities would use solar panels, wind turbines, wave energy converter, algae bioreactor, tidal generator, flywheel energy storage, heat exchange, compressed air, and underwater pump energy storage. 


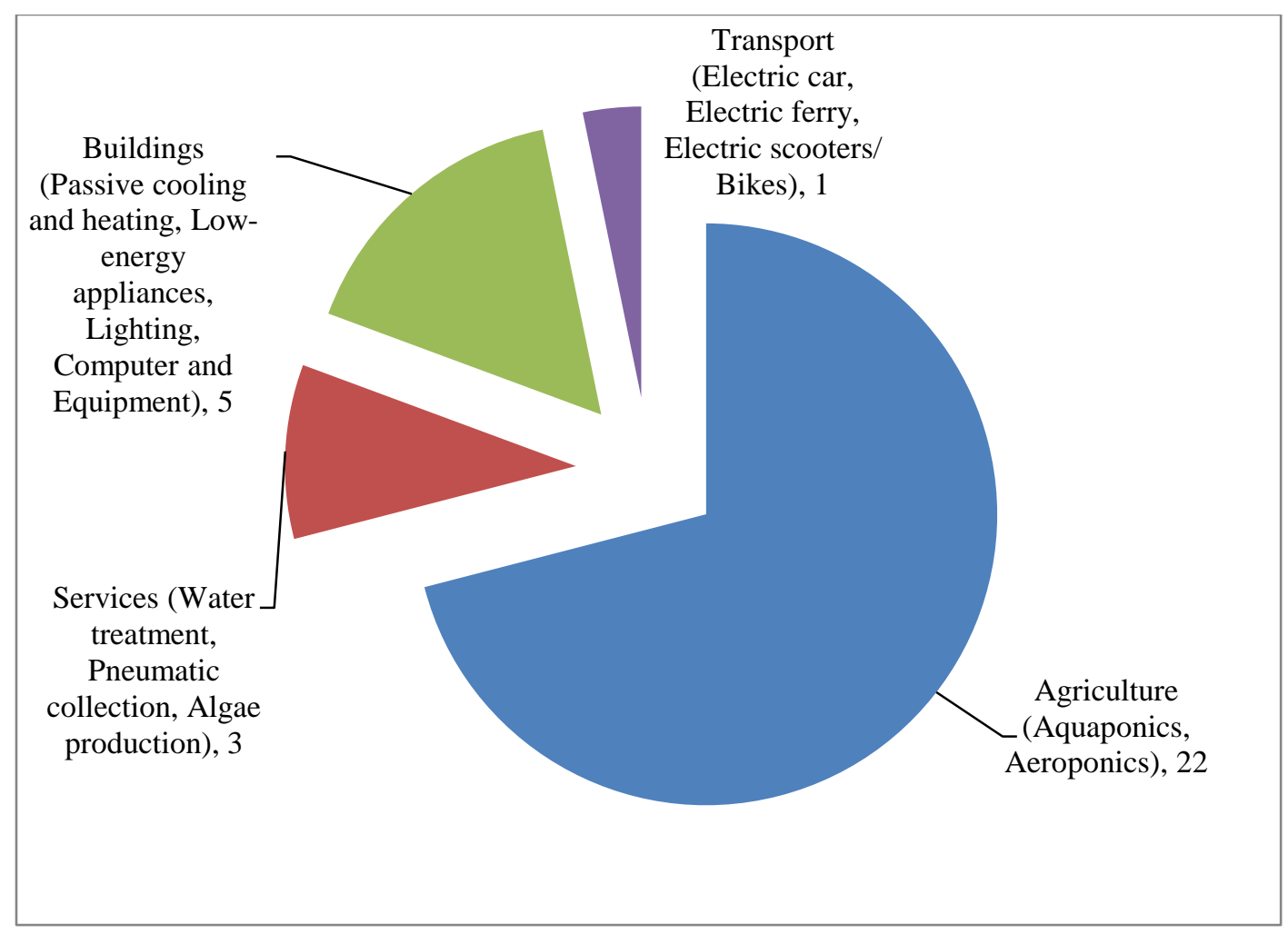

Figure 6: Daily Energy (kWh) requirement Per Capita

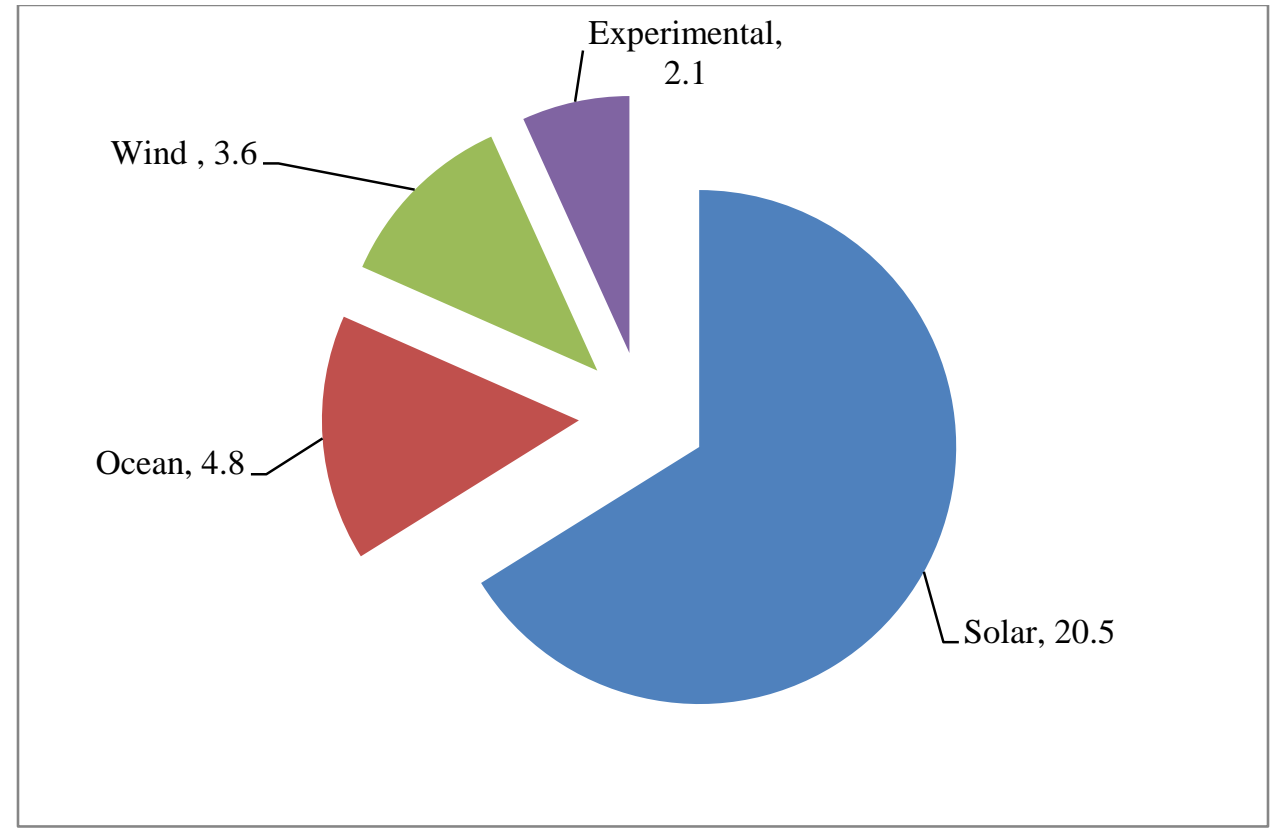

Figure 7: Production of Energy (kWh) from Different Sources 


\subsubsection{Water:}

Clean water is an essential element for human health, wellbeing, and prosperity. Whether used for drinking, cleaning, food production, or industrial output, access to sufficient water resources is a basic human need (Keiser and Shapiro, 2018; Hove et al., 2019). Access to sufficient and safe sanitation facilities is also vital for hygiene, disease prevention, and human health (Guo et al., 2017). Access to improved water sources is increasing across the world, rising from 76 percent of the global population in 1990 to 91 percent in 2015 (Ritchie and Roser, 2019). The earth's freshwater resources are subject to increasing pressure in the form of consumptive water use and pollution (Postel, 2000; WWAP, 2003, 2006, 2009; Jenny et al.,2016). The current water footprint per capita in many countries is very high with a mean global value of 3,797 liters per capita per day (Hoekstra and Mekonnen, 2012; Water Footprint Network, 2019). There are a variety of solutions to reduce this water footprint (Hoekstra, 2013). The current global average water footprint per capita per day is roughly equal to 3440 liters per capita per day. There is, however, a big difference when the water footprint of different regions or countries is compared. For instance, in the United States, the average water footprint is $2480 \mathrm{~m}^{3}$ per capita per year while in China the average value stands at $700 \mathrm{~m}^{3}$ per capita per year (Hoekstra and Chapagain, 2006). While the above-mentioned water footprint is very high, there are methods to reduce this in a sustainable way (Ridoutt and Pfister, 2010). The main solution to address the water demand in the proposed floating cities is to reduce the water footprint. Thus on a high safe side if it is assumed that the water footprint per capita on a sustainable floating city will be 583 liters per day, out of which 388 liters will be used for agricultural purpose, 115 liters for domestic purpose and 80 liters for industrial purpose, then such requirement can be met through the potable and non-potable arrangement. These potable and non-potable arrangements may include roof collection, dehumidifier, atmospheric water collector, renewable desalination facility, wastewater treatment facility, gray water treatment facility, water storage, deployable water bladder and public realm collection (Ray and Shaw, 2019; Hamlyn-Harris et al., 2019).

\subsubsection{Food:}

The result of the data collected by National Geographic during the past fifty years (1961-2011) shows the daily different food consumption of a human is approximately 1878 grams (National Geographic, 2011; Kahn and Stralka, 2009). The description of these different foods is shown in figure 8 . Based on these results, different types of meat account for $9 \%$ of the daily food. 
Overall, these items which constitute the daily food consumption (1878 grams) can be classified into proteins (470 grams), carbs (470 grams), and fiber nutrients (939 grams). A recent study that explored the average land-use area needed to produce one unit of protein by food type concluded that beef and mutton have the highest environmental footprint as it needs 1.02 sqm to produce one gram of protein (Clark and Tilman, 2017). They (Clark and Tilman) and other researchers also conclude that plant-based foods have the lowest environmental impacts (O'Keefe, 2019; Lazzarini et., 2017). Adopting alternative agricultural production systems, increasing agricultural input efficiency, and understating how food choice drive environmental degradation is necessary for reducing agriculture's environmental impacts (Altieri, 2018; Van-Vuuren et al., 2018). In other words, eliminating meat and embracing a plant-based diet can significantly reduce strain on land, energy, and water resources. El-Essawy and Sewilam (2019) viewed aquaponics with huge potential and sustainable solution since it demonstrates promising results for urban food development while providing new entrepreneurship and start-up opportunities. To make the floating cities sustainable, it will be important to adopt the concept of indoor farming, outdoor farming, 3D ocean farming, aquaponics and aeroponics as described in figure 9 (Martin and Evans, 2018; Cappiello, 2019; Gokhberg et al., 2019). There are several challenges with indoor, outdoor and vertical farming including the costs related to the operation, infrastructure, energy, and management (Van der Valk, 2012; Van Tuijl et al., 2018). Similarly, Uriarte et al., (2019) in their research related to seafood production identified many challenges associated with larviculture. The challenges with aquaponics and aeroponics are also well described in several studies (Goddek et al., 2015; Buckseth et al., 2016). To effectively address all these challenges and to meet the food requirement in a sustainable way in the proposed floating cities, further research in these areas is required. 


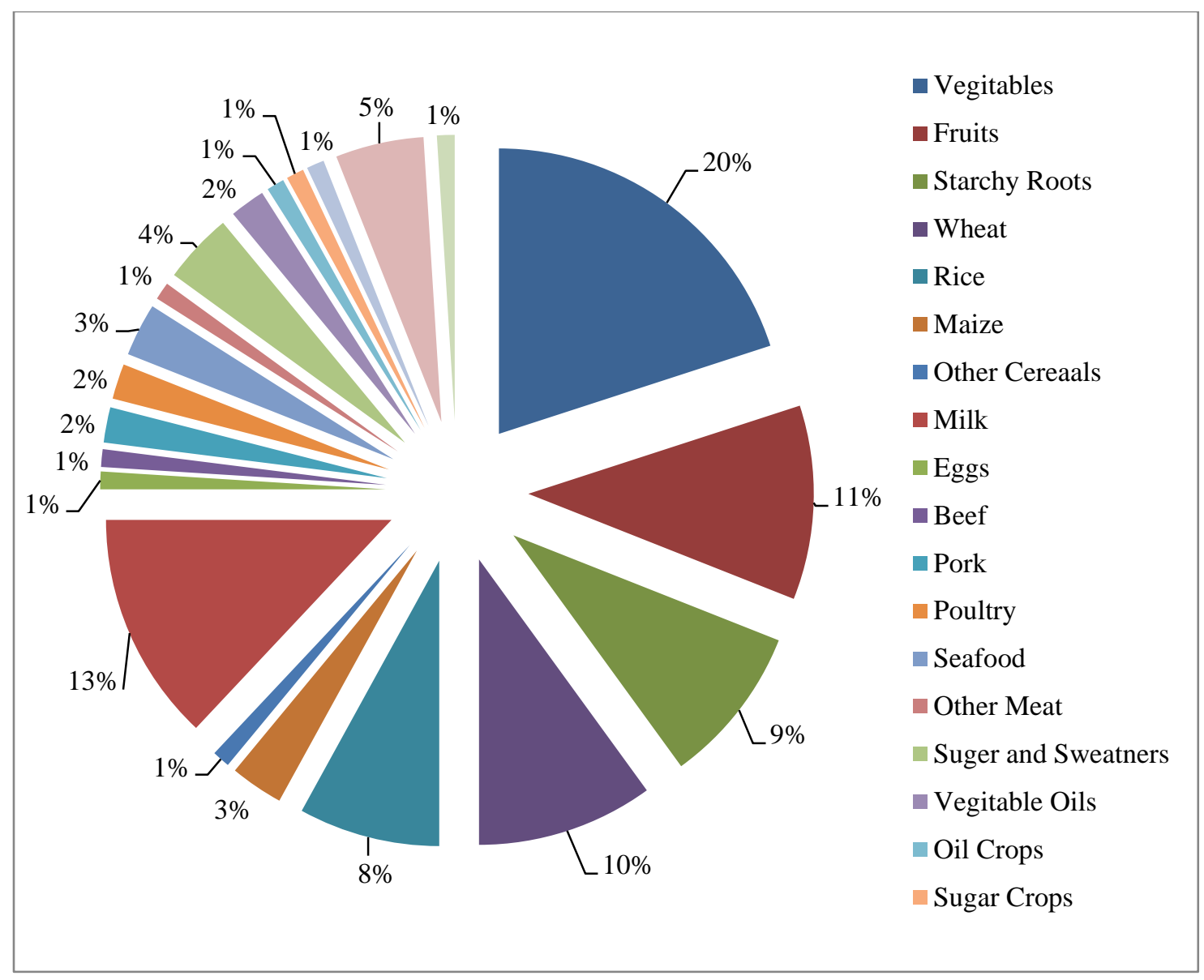

Figure 8: Daily Food Consumption (National Geographic, 2011)
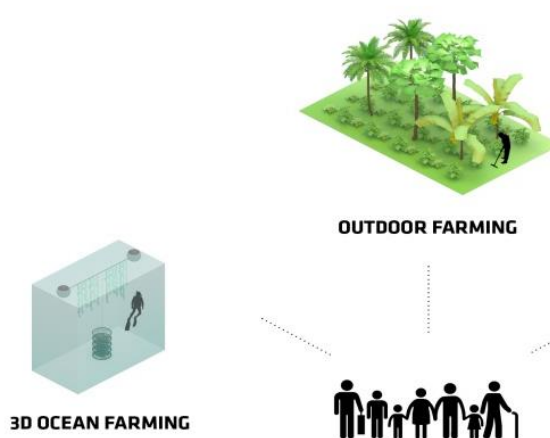

OUTDOOR FARMING
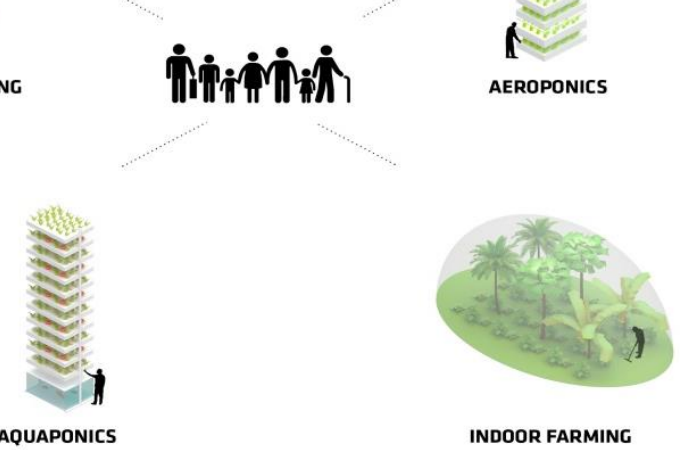


\section{Figure 9: Proposed Food Production in Floating Cities}

\subsubsection{Waste:}

The World Bank data shows that in 2016, the world generated 267 million tons of plastic waste which represents $12 \%$ of all municipal solid waste. Meanwhile, an estimated 1.8 billion tons of carbon dioxide-equivalent $\left(\mathrm{CO}_{2}\right.$-equivalent) greenhouse gas emissions were generated from solid waste management in 2016. This is about 5 percent of global emissions. Without improvements in the sector, solid waste-related emissions are anticipated to increase to 2.9 billion tons of $\mathrm{CO}_{2}$-equivalent by 2050 (Kaza et al., 2018). Currently, the way the global waste which is 2.21 billion tons per year, is treated or disposed of is not sustainable at all (figure 10). Around $33 \%$ of this waste is dumped openly. On average, the global waste generation per capita per day is 815 grams which are normally composed of organic waste (621 grams) and recyclable waste (194 grams). In some countries, however, the municipal solid waste generation reaches 2.7 $\mathrm{kg}$ per capita per day (Zafar, 2018). Organic waste is further composed of food items, food scraps, leaves, agricultural waste, and sewage waste (Otoma et al., 2013; Lagerkvist and Dahlén, 2019; Umar, 2020). Wood, textiles, metal, glass, paper, and cardboard can be classified as recyclable waste (Ayodele et al., 2018; Saeed et al., 2009). Recycling and reusing of waste will be one of the main methods to make the floating cities sustainable in relation to waste generation and its disposal. To effectively treat and recycle the waste generated in a sustainable floating city, the following arrangement should be incorporated in such cities (ZWDG, 2019; Talip et al., 2019; Yeo et al., 2019; Lewandowska and Szymańska, 2019).
a) Waste Collection System
b) Exchange Hub
c) Community compost Garden
d) Treatment Swale
e) Anaerobic Digester
f) Washing Center
g) Algae Filtration 


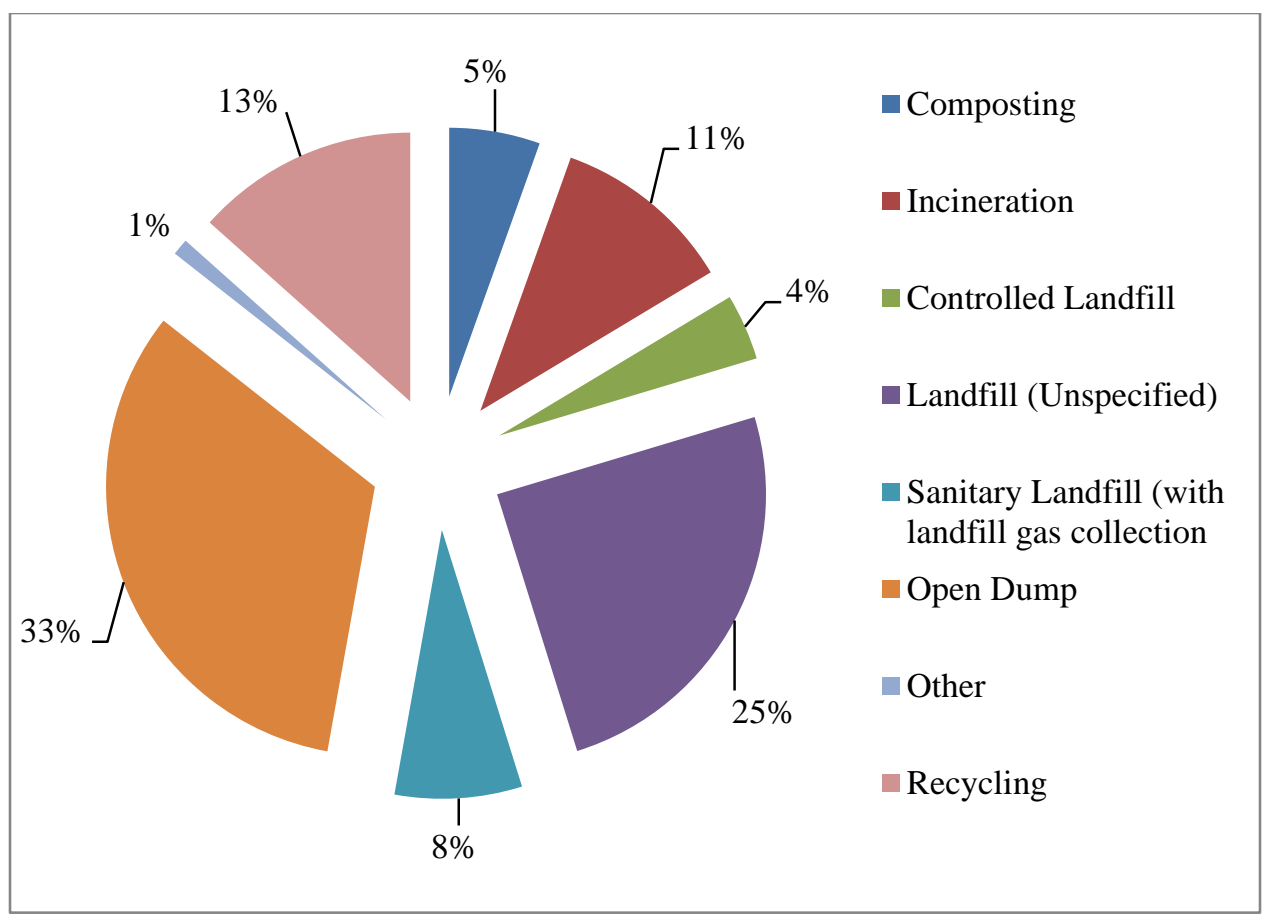

Figure 10: Global Waste Treatment and Disposal

\subsubsection{Mobility:}

Sustainability in transportation usually refers to the contribution to the sustainable development of a community that has and uses a certain system (Jha et al., 2014; Martins et al., 2019). Traditionally, the development of transportation infrastructure is based on guidelines that minimized the initial operating costs and emphasized traffic mobility considering social and environmental necessities. Mehar et al. (2014) produced research about sustainable transportation systems that aim to reduce pollution and the emissions of greenhouse effect gases. The focus of their research was electric vehicles, where they described the components of sustainable means of transportation and their solutions, projects, and standardization. For many authors, a transportation system is composed of three principal categories: fleet management, schedule planning, and energy usage (Hoff et al., 2010; Petering, 2011; Yan and Wu, 2012; Li et al., 2019). These categories if managed and well planned provide a reduction of $\mathrm{CO}_{2}$ emission in transportation activities. The negative effects of transportation on the environment have led researchers to focus on green transportation programming in the last few years. According to Salehi et al. (2017), transportation activity has harmful environmental effects. This sector emits a considerable amount of greenhouse gases. The International Council for Research and 
Innovation in Building and Construction (CIB) under its Smart City Vision and Research Roadmap considered the following components for smart and sustainable mobility (CIB, 2016).
a) Fast and Easy Mobility
b) Smart Traffic System
c) Less Time in Traffic
d) Less Cars
e) Well-Connected to Other Cities
f) Alternative to Travel
g) Intelligent Public Transport Systems

Sustainable mobility in floating cities could be achieved through a mixed-mode of electric shared and connected transportation systems. The city could be connected through different loops where different approaches of mobility can be adopted. For instance, the neighborhood loops and village loops which may have a distance of $500 \mathrm{~m}$ to $1000 \mathrm{~m}$ could be traveled through walking. Similarly, the bicycle could be used to travel on civic loops which may have a total distance of up to $3 \mathrm{~km}$. electric boats may be utilized in the water loops of certain distances. Electric boats, electric cars, and even drones could be utilized for deliveries. Unmanned Aerial Vehicles (UAVs) can be used for environmental monitoring, traffic management, pollution monitoring, civil security control, and merchandise delivery (Mohamed et al., 2018; Qi et al., 2019). UAV applications among several others can provide cost-effective services to help achieve the objectives of smart and sustainable floating cities. Currently, there are, however, several issues related to the UAV application for the transportation system in smart cities (Menouar et al., 2017). These issues are related to regulations that can allow UAVs to be used for the transportation system. Similarly, the energy or the battery storage capacity of the UAV is also considered as the main challenge that restricts its applications (Gadalla and Zafar, 2016). Similarly, the speed of UAV as compared with the vehicles on the road is comparatively low, this considered as a disadvantage of UAV. There is, however, great work going on around the world and it is expected that all these challenges associated with the UAV application in the transportation system will be resolved in near future (Al-Kaff et al., 2018). 


\subsubsection{Habitat Regeneration:}

The data collected through the systematic review suggest that bio-rock is a unique ocean technology that produces the only marine construction material that grows, heals itself, and becomes stronger with age. Bio-rock applies safe extremely low voltage direct current trickle charges to steel structures of any size or shape (Karissa et al, 2012; Goreau and Prong, 2017). Electric current can be produced by energy from the sun, winds, waves, and ocean currents generated directly at the site. This completely prevents any rusting or corrosion and grows solid limestone rock in seawater that is two to three times stronger than ordinary concrete (Patel, 2019). Similarly, the existing literature suggests that bio-rock reefs have the ability to survive the strongest hurricanes (well et al., 2010). Bio-rock rapidly regenerates coral reefs, oysters, seagrasses, salt marshes, mangroves, fisheries, and coastal ecosystems where there is no natural recovery (Wells et al., 2010). Similarly, Goreau and Prong (2017) in their research on bio-rock technology noted that bio-rocks are cheaper than concrete or rock sea walls and breakwaters, and are much more effective at shore protection and beach growth. It greatly increases settlement, growth, survival, and resistance to extremely high temperatures and pollution stress for corals and all marine organisms. Coral reefs made of bio-rock survive severe bleaching events, and rapidly regenerate reefs and fisheries (Berger et al., 2012). Floating Bio-rock reefs filter and clean polluted coastal waters (BIC, 2017). Using this technology, Japanese scallop landings were 400,000-600,000 megaton in 2016 and scallops are the most valuable in the Japanese mariculture industry (Kosaka, 2016). Bio-rock technology provides greater benefits, faster results, and lower costs than any other alternative to solve a wide range of crucial marine management problems (DeGeorges, 2017; Rizal and Faizal, 2018). Overall, there could be a wide range of applications and benefits of bio-rock technology that could be utilized in the floating sustainable cities. These applications and benefits of bio-rock technology are summarized as under.

i) Coral Reef Restoration and Protection against Global warming

ii) Marine Construction

iii) Shore Protection

iv) Beach Erosion 
v) Adaptation to sea-level rise

vi) Oyster Reef Restoration

vii) Sea Grass Restoration

viii) Salt Marsh Restoration

ix) Fisheries Restoration

x) Sustainable Aquaculture

Overall the above discussion reveals that there are different methods that can be incorporated in the floating cities to achieve the leading sustainability factors discussed in this paper. Adopting the concept of floating cities will not only provide a solution to global urbanization but also the achievement of different factors in a sustainable manner in these self-sufficient cities can serve as a role model of the existing cities on the land to promote sustainability.

The next section provides a conclusion of the paper.

\section{Conclusion:}

Globally, the scope of sustainability for rapid urbanization is huge which still has many challenges. People are moving to cities due to different reasons thus these cities are rapidly growing and not prepare to meet the citizen requirement in a sustainable way. Most of the cities are located near the coastal areas which have several threats including sea rise due to climate change. In fact, cities around the world consumed much of the natural resources and thus have become the main contributors to global warming and climate change. Challenges associated with cities are going to be expanding due to the population increase. To meet these challenges, a specific focus should be given to urban planning and design. Expanding the cities is one of the solutions; however, it may not be sustainable in the future as much of the area on the earth is occupied by the oceans. Using underground spaces has provided some partial solutions to this, keeping in mind that challenges associated with the underground spaces cannot be ignored. This article, therefore, considers the concept of floating cities to meet the future requirement of urbanization. The concept of floating cities is not new as there are pieces of evidence that prove 
that such cities existed in the past. Even, recently in a high-level meeting of the United Nations, this approach has been discussed. The main question, however, is how these cities could be sustainable. This article, therefore, attempted to find some solution to the main factors associated with the sustainability of such cities. A mixed research approach consists of qualitative and quantitative methods were adopted to extract and rank the main factors that the selected respondents considered as the main priority of sustainable cities. Finally, the top six suitability factors based on the mean score were selected. The selected sustainability factors considered in this article were;
a) Energy
b) Water
c) Food
d) Waste
e) Mobility
f) Habitat Generation

In the next phase of the research, a qualitative approach using a systematic review was adopted to find the solution to achieve the above-mentioned factors in a sustainable way. The energy requirement per capita per day in a floating sustainable city $(=31 \mathrm{kWh})$ needs to be met from clean and renewable energy resources that include solar, wind, ocean, and experimental. The current water footprint per capita around the world is very high and non-sustainable. Therefore in a sustainable floating city, this footprint needs to be reduced to 583 liters per day, then it would be possible to meet this water requirement through potable and non-potable arrangements. The daily food consumption per capita is approximately 1,878 grams. Meat as a major source of protein constitutes $9 \%$ of the daily food requirement; however, it has the highest environmental footprint. Plant-based foods have the lowest environmental impacts and therefore different techniques should be applied to achieve this in a floating sustainable city. Similarly, to effectively treat and recycle the waste generated (=815 grams/capita/day) in a sustainable floating city, arrangements such as waste collection system, exchange hub, community compost garden, treatment swale, anaerobic digester, washing center, and algae filtration need to be part of sustainable floating cities. Sustainable mobility in a floating city could be achieved through walking, using bicycles, electric boats, electric cars, drones, and Unmanned Aerial Vehicles 
(UAVs). The role of habitat regeneration to achieve sustainability in floating cities will be crucial. The use of bio-rock technology will help to achieve a variety of floating cities' requirements in a sustainable way. Since this research considered few factors related to the sustainability of floating cities and explore the solution to achieve these factors in a sustainable manner, further research needs to be conducted to explore the remaining factors and how those factors could be achieved in a sustainable way. Of course, the concept of floating cities is at its initial stage which has multi-dimensions and has a huge potential for multidisciplinary research. Considering all dimensions of sustainable floating cities will help to manage future urbanization globally. Since this research is exploratory in nature that reports the results from the existing literature on how to achieve the main sustainability factors in the floating cities, further research is recommended to expand these factors and investigate more practical and in-depth solutions for such factors. Although, the human (social) factors are briefly discussed in this paper, however, such factors are quite important and will play a significant role in the success of floating cities. Further studies are therefore recommended in the areas of human factors associated with the floating cities. This will help place managers to understand the implications of these factors in the context of floating cities and to develop strategies to achieve the required level of these factors. The perception of the public on the future floating cities needs to be clearly assessed and understood so that the developers and the place managers know the possible expectation of the main stakeholders. While developing a real project even on a small scale to assess the satisfaction level of the potential residents appears to be quite expensive, place management research community needs to find alternative ways that how such satisfaction can be gauged and improved without having a real experience of living in floating cities. Furthermore, most of the solutions related to different sustainability factors presented in this paper can be classified as technologically advanced solutions. These solutions are to be adopted by the main stakeholders of these floating cities in their daily life. This change and adaptation will not only require a certain level of skills and education but will also have some impact on the residents' social life. Such factors are therefore equally important to be addressed in further research. 


\section{Appendix I:}

Parameters for the review protocol for floating sustainable cities' key factors (Stage I).

\begin{tabular}{|c|c|c|c|c|c|c|c|}
\hline \multicolumn{8}{|c|}{ Sustainable Cities Key Factors } \\
\hline Keywords & Period & $\begin{array}{l}\text { Inclusion } \\
\text { Criteria }\end{array}$ & Exclusion Criteria & Database & $\begin{array}{l}\text { Total } \\
\text { Downloaded } \\
\text { Articles/ } \\
\text { Reports }\end{array}$ & $\begin{array}{l}\text { Total } \\
\text { Articles/ } \\
\text { Reports } \\
\text { After } \\
\text { Criteria }\end{array}$ & Derived Factors \\
\hline $\begin{array}{l}\text { Sustainability of } \\
\text { Coastal Cities, } \\
\text { Sustainability } \\
\text { Management in } \\
\text { Coastal/Floating } \\
\text { Cities, } \\
\text { Sustainable } \\
\text { Development in } \\
\text { Coastal/ } \\
\text { Floating Cities }\end{array}$ & \begin{tabular}{|l|} 
January 2010 \\
to June 2019
\end{tabular} & $\begin{array}{l}\text { Publications } \\
\text { reporting the } \\
\text { history of } \\
\text { floating cities } \\
\text { Publications } \\
\text { comparing } \\
\text { floating cities } \\
\text { with other cities }\end{array}$ & $\begin{array}{l}\text { Publications where the } \\
\text { keywords are not in the title, } \\
\text { abstract or in } \\
\text { the keywords } \\
\text { Publications in non-English } \\
\text { language }\end{array}$ & $\begin{array}{l}\text { Web of } \\
\text { Science } \\
\text { PRO QUEST } \\
\text { SCOPUS } \\
\text { Science } \\
\text { Direct }\end{array}$ & 87 & 43 & $\begin{array}{l}\text { 1. Design and Materials } \\
\text { 2. Land Management } \\
\text { 3. Energy } \\
\text { 4. Human Comfort } \\
\text { (Temperature and Humidity) } \\
\text { 5. Food } \\
\text { 6. Mobility } \\
\text { 7. Water Management } \\
\text { 8. Waste Management } \\
\text { 9. Habitat Regeneration } \\
\text { 10. Risk Management }\end{array}$ \\
\hline
\end{tabular}




\section{Appendix II:}

Parameters for the review protocol for floating sustainable cities (Stage II).

\begin{tabular}{|c|c|c|c|c|c|c|}
\hline \multicolumn{7}{|c|}{ History of Floating Cities } \\
\hline Keywords & Period & Inclusion Criteria & Exclusion Criteria & Database & $\begin{array}{l}\text { Total } \\
\text { Downloaded } \\
\text { Articles/ } \\
\text { Reports }\end{array}$ & $\begin{array}{l}\text { Total } \\
\text { Articles/ } \\
\text { Reports After } \\
\text { Criteria }\end{array}$ \\
\hline $\begin{array}{l}\text { History of floating } \\
\text { cities, } \\
\text { History of floating } \\
\text { metropolis }\end{array}$ & No Cap & $\begin{array}{l}\text { Publications/ Reports / news } \\
\text { articles reporting the history of } \\
\text { floating cities } \\
\text { Publications/ Reports / news } \\
\text { articles comparing floating cities } \\
\text { with other cities }\end{array}$ & $\begin{array}{l}\text { Publications/ Reports / news } \\
\text { articles where the keywords } \\
\text { are not in the title, abstract or in } \\
\text { the keywords } \\
\text { Articles/ Reports / news articles } \\
\text { in non-English language }\end{array}$ & $\begin{array}{l}\text { Google Chrome } \\
\text { was used as a } \\
\text { search tool using } \\
\text { the key words }\end{array}$ & 57 & 14 \\
\hline \multicolumn{7}{|c|}{ Sustainability Factors } \\
\hline $\begin{array}{l}\text { Clean energy, } \\
\text { Energy Efficiency, } \\
\text { Energy efficiency } \\
\text { techniques, } \\
\text { Solar, wind, ocean } \\
\text { and experimental } \\
\text { energy }\end{array}$ & $\begin{array}{l}\text { January, } 2014 \\
\text { - April, } 2019\end{array}$ & $\begin{array}{l}\text { Publications/ Reports on energy } \\
\text { requirement per capita } \\
\text { Publications/ Reports on energy } \\
\text { efficiency } \\
\text { Publications/ Reports on different } \\
\text { forms of renewable and clean } \\
\text { energy }\end{array}$ & $\begin{array}{l}\text { Publications/ Reports where the } \\
\text { keywords are not in the title, } \\
\text { abstract or in the keywords } \\
\text { Articles/ Reports in non- } \\
\text { English language }\end{array}$ & $\begin{array}{l}\text { Web of Science } \\
\text { PRO QUEST } \\
\text { SCOPUS } \\
\text { Science Direct } \\
\text { Google Chrome }\end{array}$ & 43 & 14 \\
\hline 2. Water & & & & & & \\
\hline $\begin{array}{l}\text { Water footprint, } \\
\begin{array}{l}\text { Reduction in water } \\
\text { footprint, }\end{array} \\
\begin{array}{l}\text { Sustainable water } \\
\text { footprint, }\end{array}\end{array}$ & $\begin{array}{l}\text { January, } 2000 \\
\text { to April, } 2019\end{array}$ & $\begin{array}{l}\text { Publications/ Reports on water } \\
\text { footprint per capita } \\
\text { Publications/ Reports on } \\
\text { sustainable water footprint } \\
\text { Publications/ Reports on potable } \\
\text { and non-potable water }\end{array}$ & $\begin{array}{l}\text { Publications/ Reports where the } \\
\text { keywords are not in the title, } \\
\text { abstract or in the keywords } \\
\text { Articles/ Reports in non- } \\
\text { English language }\end{array}$ & $\begin{array}{l}\text { Web of Science } \\
\text { PRO QUEST } \\
\text { SCOPUS } \\
\text { Science Direct }\end{array}$ & 52 & 16 \\
\hline
\end{tabular}




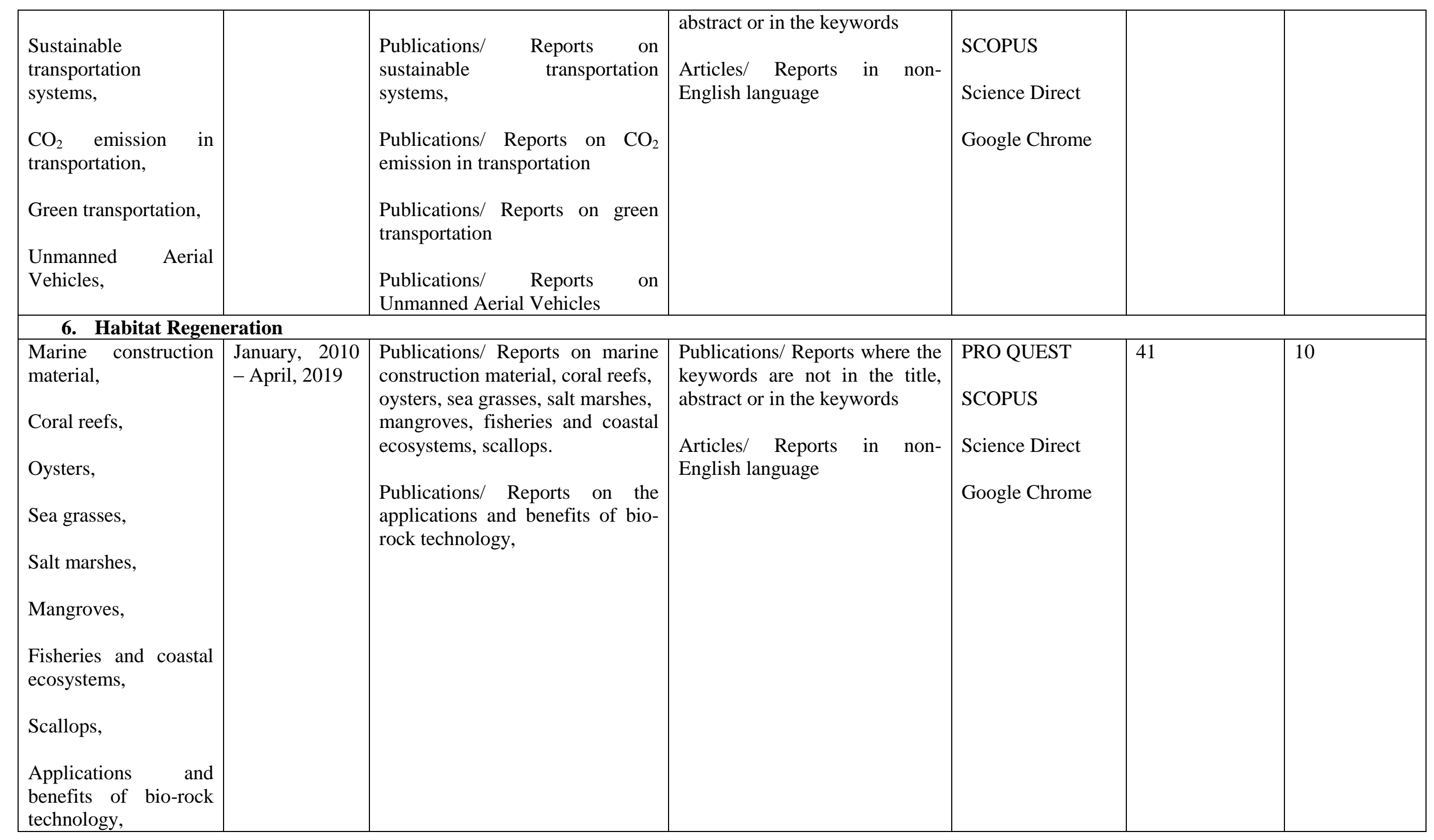




\section{Appendix III:}

Details of Systematic Review for Main Sustainability Factors

\begin{tabular}{|c|c|c|c|c|c|c|c|c|c|c|}
\hline Factor & $\begin{array}{l}\text { Records } \\
\text { Identified } \\
\text { Through } \\
\text { Database } \\
\text { Search }\end{array}$ & $\begin{array}{l}\text { Records } \\
\text { After } \\
\text { Duplicates } \\
\text { Removed }\end{array}$ & $\begin{array}{l}\text { Record } \\
\text { Screene } \\
\text { d }\end{array}$ & $\begin{array}{l}\text { Records } \\
\text { Exclude } \\
\text { d }\end{array}$ & $\begin{array}{l}\text { Full- } \\
\text { Text } \\
\text { Articles } \\
\text { Assessed } \\
\text { for } \\
\text { Eligibilit } \\
\text { y }\end{array}$ & $\begin{array}{l}\text { Full- } \\
\text { Text } \\
\text { Articles } \\
\text { Exclude } \\
\text { d }\end{array}$ & $\begin{array}{l}\text { Studies } \\
\text { Included in } \\
\text { Quantitative } \\
\text { Synthesis }\end{array}$ & Item Type & Year & Reference \\
\hline \multirow{14}{*}{ Energy } & \multirow{14}{*}{101} & \multirow{14}{*}{96} & \multirow{14}{*}{96} & \multirow{14}{*}{53} & \multirow{14}{*}{43} & \multirow{14}{*}{29} & \multirow{14}{*}{14} & Book & 2014 & Rassia and Pardalos (2014) \\
\hline & & & & & & & & $\begin{array}{l}\text { Journal } \\
\text { Paper }\end{array}$ & 2019 & Nagpal et al. (2019) \\
\hline & & & & & & & & $\begin{array}{l}\text { Journal } \\
\text { Paper }\end{array}$ & 2018 & Chel and Kaushik (2018) \\
\hline & & & & & & & & Report & 2016 & IEA (2016) \\
\hline & & & & & & & & Web Page & 2016 & Visual Capitalist (2016) \\
\hline & & & & & & & & Web Page & 2019 & OCEANIX (2019) \\
\hline & & & & & & & & $\begin{array}{l}\text { Journal } \\
\text { Paper }\end{array}$ & 2019 & Umar and Egbu (2019) \\
\hline & & & & & & & & $\begin{array}{l}\text { Journal } \\
\text { Paper }\end{array}$ & 2017 & Wang et al. (2017) \\
\hline & & & & & & & & $\begin{array}{l}\text { Journal } \\
\text { Paper }\end{array}$ & 2016 & Umar and Wamuziri (2016) \\
\hline & & & & & & & & $\begin{array}{l}\text { Journal } \\
\text { Paper }\end{array}$ & 2018 & Umar, (2018-a) \\
\hline & & & & & & & & $\begin{array}{l}\text { Journal } \\
\text { Paper }\end{array}$ & 2016 & Lund and Boyd (2016) \\
\hline & & & & & & & & $\begin{array}{l}\text { Journal } \\
\text { Paper }\end{array}$ & 2018 & Umar (2018-b) \\
\hline & & & & & & & & $\begin{array}{l}\text { Journal } \\
\text { Paper }\end{array}$ & 2016 & Uihlein and Magagna (2016) \\
\hline & & & & & & & & $\begin{array}{l}\text { Journal } \\
\text { Paper }\end{array}$ & 2019 & Umar et al. (2020-b) \\
\hline \multirow[t]{2}{*}{ Water } & \multirow[t]{2}{*}{123} & \multirow[t]{2}{*}{102} & \multirow[t]{2}{*}{102} & \multirow[t]{2}{*}{50} & \multirow[t]{2}{*}{52} & \multirow[t]{2}{*}{36} & \multirow[t]{2}{*}{16} & $\begin{array}{l}\text { Article } \\
\text { (Online) }\end{array}$ & 2019 & Ritchie and Roser(2019) \\
\hline & & & & & & & & Journal & 2000 & Postel (2000) \\
\hline
\end{tabular}




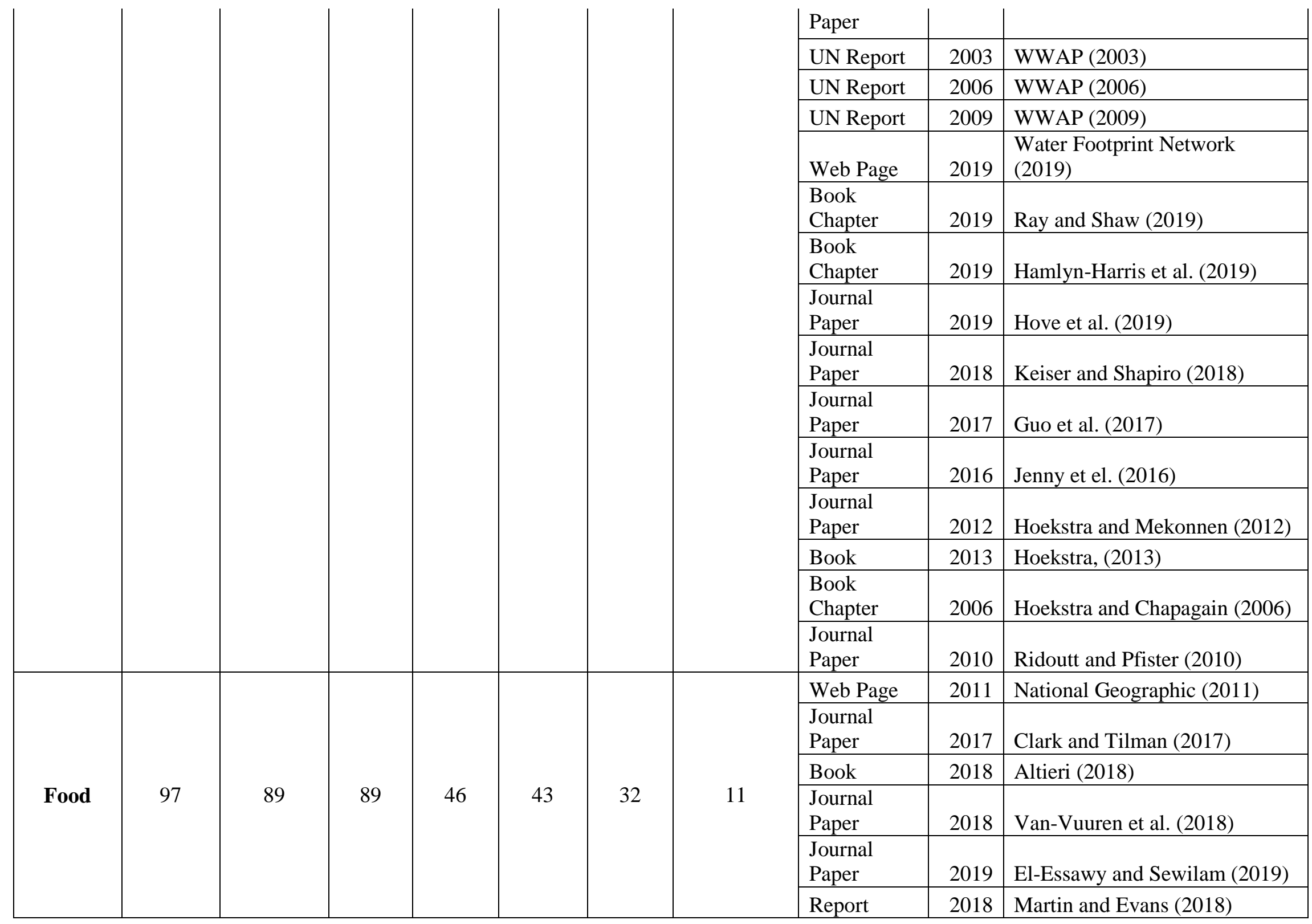




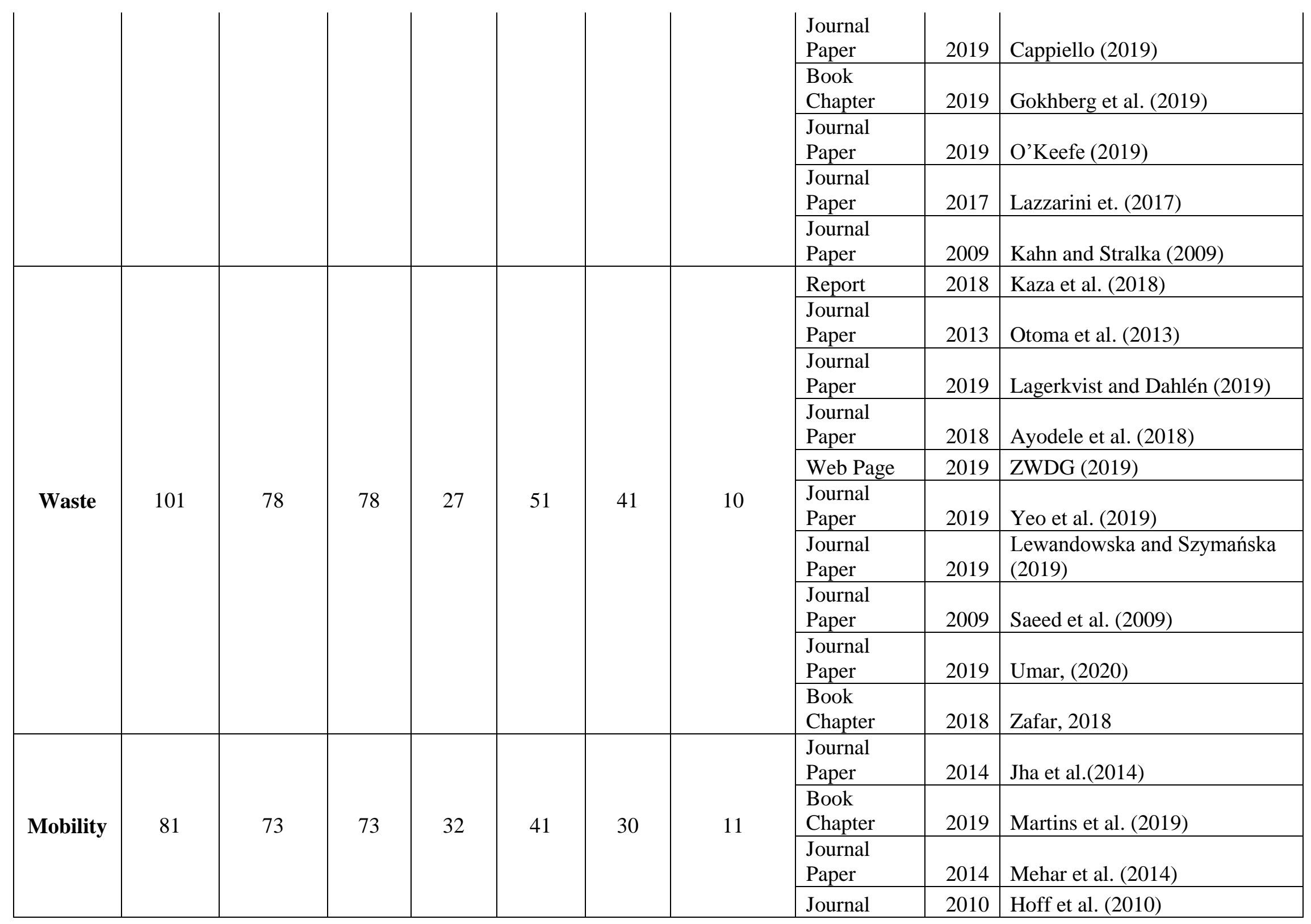




\begin{tabular}{|c|c|c|c|c|c|c|c|c|c|c|}
\hline & & & & & & & & Paper & & \\
\hline & & & & & & & & $\begin{array}{l}\text { Journal } \\
\text { Paper }\end{array}$ & 2011 & Petering (2011) \\
\hline & & & & & & & & $\begin{array}{l}\text { Journal } \\
\text { Paper }\end{array}$ & 2012 & Yan and $\mathrm{Wu}(2012)$ \\
\hline & & & & & & & & $\begin{array}{l}\text { Journal } \\
\text { Paper } \\
\end{array}$ & 2019 & Li et al. (2019) \\
\hline & & & & & & & & $\begin{array}{l}\text { Journal } \\
\text { Paper } \\
\end{array}$ & 2017 & Salehi et al. (2017) \\
\hline & & & & & & & & Report & 2016 & CIB (2016) \\
\hline & & & & & & & & $\begin{array}{l}\text { Journal } \\
\text { Paper } \\
\end{array}$ & 2018 & Mohamed et al. (2018) \\
\hline & & & & & & & & $\begin{array}{l}\text { Journal } \\
\text { Paper }\end{array}$ & 2019 & Qi et al. (2019) \\
\hline \multirow{10}{*}{$\begin{array}{c}\text { Habitat } \\
\text { Regener } \\
\text { ation }\end{array}$} & \multirow{10}{*}{79} & \multirow{10}{*}{63} & \multirow{10}{*}{63} & \multirow{10}{*}{22} & \multirow{10}{*}{41} & \multirow{10}{*}{21} & \multirow{10}{*}{10} & $\begin{array}{l}\text { Book } \\
\text { Chapter }\end{array}$ & 2012 & Karissa et al. (2012) \\
\hline & & & & & & & & $\begin{array}{l}\text { Journal } \\
\text { Paper }\end{array}$ & 2017 & Goreau and Prong (2017) \\
\hline & & & & & & & & Book & 2019 & Patel (2019) \\
\hline & & & & & & & & $\begin{array}{l}\text { Journal } \\
\text { Paper } \\
\end{array}$ & 2010 & well et al. (2010) \\
\hline & & & & & & & & Web Page & 2017 & BIC (2017) \\
\hline & & & & & & & & $\begin{array}{l}\text { Book } \\
\text { Chapter }\end{array}$ & 2016 & Kosaka (2016) \\
\hline & & & & & & & & $\begin{array}{l}\text { Journal } \\
\text { Paper } \\
\end{array}$ & 2017 & DeGeorges (2017) \\
\hline & & & & & & & & $\begin{array}{l}\text { Journal } \\
\text { Paper }\end{array}$ & 2018 & Rizal and Faizal (2018) \\
\hline & & & & & & & & $\begin{array}{l}\text { Book } \\
\text { Chapter }\end{array}$ & 2012 & Berger et al. (2012) \\
\hline & & & & & & & & $\begin{array}{l}\text { Journal } \\
\text { Paper } \\
\end{array}$ & 2005 & Goreau and Hilbertz (2005) \\
\hline Total & 582 & 501 & 501 & 230 & 271 & 189 & 72 & & & \\
\hline
\end{tabular}




\section{References:}

Aberbach, J. D., \& Christensen, T. (2017). Academic Autonomy and Freedom under Pressure: Severely Limited, or Alive and Kicking? Public Organization Review. https://doi.org/10.1007/s11115-017-0394-2.

Ahmadi, H.B., Kusi-Sarpong, S. and Rezaei, J., 2017. Assessing the social sustainability of supply chains using Best Worst Method. Resources, Conservation and Recycling, 126, pp.99-106. https://doi.org/10.1016/j.resconrec.2017.07.020.

Alexander, J.C., 2006. The meanings of social life: A cultural sociology. Oxford University Press, USA.

Al-Kaff, A., Alonso, R., Osman, M. and Hussein, A., 2018, November. Skyonyx: Autonomous uav research platform for air transportation system (atsys). In 2018 21st International Conference on Intelligent Transportation Systems (ITSC) (pp. 3550-3555). IEEE.

Altieri, M.A., 2018. Agroecology: the science of sustainable agriculture. CRC Press. Florida, United States. https://doi.org/10.1201/9780429495465.

Armindo, J., Fonseca, A., Abreu, I. and Toldy, T., 2019. Perceived importance of sustainability dimensions in the Portuguese metal industry. International Journal of Sustainable Development \& World Ecology, 26(2), pp.154-165. https://doi.org/10.1080/13504509.2018.1508524.

Ayodele, T.R., Alao, M.A. and Ogunjuyigbe, A.S.O., 2018. Recyclable resources from municipal solid waste: assessment of its energy, economic and environmental benefits in Nigeria. Resources, Conservation and Recycling, 134, pp.165-173. https://doi.org/10.1016/j.resconrec.2018.03.017.

BBC (British Broadcasting Corporation), 2018. The floating Aztec city. BBC, London, United Kingdom. See: http://www.bbc.com/future/story/20180622-tenochtitlan-the-mexicanmetropolis (accessed 12/05/2019).

Beckmann, S.C. and Zenker, S., 2012, May. Place branding: A multiple stakeholder perspective. In 41st European Marketing Academy Conference, Lisbon, Portugal (pp. 22-25). See: https://researchapi.cbs.dk/ws/portalfiles/portal/58892921/Beckmann_Zenker_EMAC_2012.pdf (accessed 16/02/2020).

Berger, N., Haseltine, M., Boehm, J.T. and Goreau, T.J., 2012. Increased oyster growth and survival using Biorock Technology. Innovative Methods of Marine Ecosystem Restoration, CRC Press, Boca Raton, pp.141-150.

Beza, B. and Hernández-Garcia, J. (2018), "From placemaking to sustainability citizenship", Journal of Place Management and Development, Vol. 11 No. 2, pp. 192-207. https://doi.org/10.1108/JPMD-06-2017-0051

Bibri, S.E. and Krogstie, J., 2017. Smart sustainable cities of the future: An extensive interdisciplinary literature review. Sustainable Cities and Society, 31, pp.183-212. https://doi.org/10.1016/j.scs.2017.02.016. 
BIC (Biorock International Corporation), 2017. A healthy Coral reef is Mother Nature at her Best. Biorock International Corporation, Thailand. See: https://www.biorock.org/ (accessed 14/05/2019).

Boisen, M., Terlouw, K., Groote, P., \& Couwenberg, O. (2018). Reframing place promotion, place marketing, and place branding - moving beyond conceptual confusion. Cities, 80, 4-11. https://doi.org/10.1016/j.cities.2017.08.021

Bolonkin, A., 2010. Floating cities on ice platform. Open Ocean Engineering Journal, 3, pp.1-11. http://dx.doi.org/10.2174/1874835X01003010001.

Bolonkin, A.A., 2011. Floating cities. In Engineering Earth (pp. 967-983). Springer, Dordrecht, Netherlands.

Broere, W., 2016. Urban underground space: Solving the problems of today's cities. Tunnelling and Underground Space Technology, 55, pp.245-248. https://doi.org/10.1016/j.tust.2015.11.012.

Bryman, A., 2016. Social research methods. Oxford university press. Oxford, United Kingdom.

Buckseth, T., Sharma, A.K., Pandey, K.K., Singh, B.P. and Muthuraj, R., 2016. Methods of prebasic seed potato production with special reference to aeroponics-A review. Scientia horticulturae, 204, pp.79-87. https://doi.org/10.1016/j.scienta.2016.03.041.

Calnek, E.E., 1972. Settlement pattern and chinampa agriculture at Tenochtitlan. American Antiquity, 37(1), pp.104-115. https://doi.org/10.2307/278892.

Cappiello, M.A., 2019. Moth and Wasp, Soil and Ocean: Remembering Chinese Scientist Pu Zhelong's Work for Sustainable Farming. Language Arts, 96(5), pp.329-334.

Chel, A. and Kaushik, G., 2018. Renewable energy technologies for sustainable development of energy efficient building. Alexandria Engineering Journal, 57(2), pp.655-669. https://doi.org/10.1016/j.aej.2017.02.027.

Cheng, P., Zhou, G. and Zheng, Z., 2009. Detecting and counting vehicles from small low-cost UAV images. In ASPRS 2009 Annual Conference, Baltimore (Vol. 3, pp. 9-13).

CIB (The International Council for Research and Innovation in Building and Construction), 2016. Research Roadmap Report Smart City Vision. CIB Publication 407. The International Council for Research and Innovation in Building and Construction, Delft, The Netherlands. See: https://site.cibworld.nl/dl/publications/CIB_Publication_407.pdf (accessed 14/05/2019).

Ciriacono, S., 2006. Building on water: Venice, Holland and the construction of the European landscape in early modern times. Berghahn Books. New York, United States.

Clark, M. and Tilman, D., 2017. Comparative analysis of environmental impacts of agricultural production systems, agricultural input efficiency, and food choice. Environmental Research Letters, 12(6), p.064016. https://doi.org/10.1088/1748-9326/aa6cd5.

Columbia University, 2019. Percentage of Total Population Living In Coastal Areas. Columbia University, New York, United States. See: https://sedac.ciesin.columbia.edu/es/papers/Coastal_Zone_Pop_Method.pdf (accessed 11/05/2019). 
Cooper, D.R., Schindler, P.S. and Sun, J., 2006. Business research methods (Vol. 9). McGrawHill Irwin. New York, United States.

Dawson, V., 2012. Science teachers' perspectives about climate change. Teaching Science: The Journal of the Australian Science Teachers Association, Vol. 58 Issue 3, p8-13.

DeGeorges, P.A., An historical overview of impacts from land-based pollution on community based natural resource management (CBNRM) as it applies to marine fisheries \& coral reefs in the tropics. J Fish Res. 2017; 1 (1): 15-27. J Fish Res 2017 Volume 1 Issue, 1.

El-Essawy, H., Nasr, P. and Sewilam, H., 2019. Aquaponics: a sustainable alternative to conventional agriculture in Egypt-a pilot scale investigation. Environmental Science and Pollution Research, 26(16), pp.15872-15883. https://doi.org/10.1007/s11356-019-04970$\underline{0}$.

El-Essawy, H., Nasr, P. and Sewilam, H., 2019. Aquaponics: a sustainable alternative to conventional agriculture in Egypt-a pilot scale investigation. Environmental Science and Pollution Research, pp.1-12. https://doi.org/10.1007/s11356-019-04970-0.

El-Shihy, A.A. and Ezquiaga, J.M., 2019. Architectural design concept and guidelines for floating structures for tackling sea level rise impacts on Abu-Qir. Alexandria Engineering Journal. https://doi.org/10.1016/j.aej.2019.05.003.

Erkens, G., Bucx, T., Dam, R., De Lange, G. and Lambert, J., 2015. Sinking coastal cities. Proceedings of the International Association of Hydrological Sciences, 372, pp.189-198. https://doi.org/10.5194/piahs-372-189-2015.

Fagan, B.M., 1984. The Aztecs. WH Freeman, New York, United States.

Ferraro, J.M., 2012. Venice: History of the Floating City. Cambridge University Press. Cambridge, United Kingdom.

Gadalla, M. and Zafar, S., 2016. Analysis of a hydrogen fuel cell-PV power system for small UAV. International Journal of Hydrogen Energy, 41(15), pp.6422-6432. https://doi.org/10.1016/j.ijhydene.2016.02.129

GCRA (Global Coral Reef Alliance), 2019. Biorock, Mineral Accretion Technolog, Seament. Global Coral Reef Alliance. Massachusetts , United States. See: http://www.globalcoral.org/biorock-coral-reef-marine-habitat-restoration/ (accessed 14/05/2019).

GCUP (Global Colloquium of University Presidents), 2005. Statement of academic freedom. Columbia University, New York, United States.

Goddek, S., Delaide, B., Mankasingh, U., Ragnarsdottir, K.V., Jijakli, H. and Thorarinsdottir, R., 2015. Challenges of sustainable and commercial aquaponics. Sustainability, 7(4), pp.4199-4224. https://doi.org/10.3390/su7044199

Gokhberg, L., Kuzminov, I., Bakhtin, P., Timofeev, A. and Khabirova, E., 2019. Emerging Technologies Identification in Foresight and Strategic Planning: Case of Agriculture and Food Sector. In Emerging Technologies for Economic Development (pp. 205-223). Springer, Cham. https://doi.org/10.1007/978-3-030-04370-4_9. 
Goreau, T. and Prong, P., 2017. Biorock electric reefs grow back severely eroded beaches in months. Journal of Marine Science and Engineering, 5(4), p.48. https://doi.org/10.3390/jmse5040048.

Goreau, T.J. and Hilbertz, W., 2005. Marine ecosystem restoration: costs and benefits for coral reefs. World resource review, 17(3), pp.375-409.

Gough, D., Oliver, S. and Thomas, J. eds., 2017. An introduction to systematic reviews. Sage Publishing, California, United States.

Graneheim, U.H. and Lundman, B., 2004. Qualitative content analysis in nursing research: concepts, procedures and measures to achieve trustworthiness. Nurse education today, 24(2), pp.105-112. https://doi.org/10.1016/j.nedt.2003.10.001.

Guo, A., Bowling, J.M., Bartram, J. and Kayser, G., 2017. Water, sanitation, and hygiene in rural health-care facilities: a cross-sectional study in Ethiopia, Kenya, Mozambique, Rwanda, Uganda, and Zambia. The American journal of tropical medicine and hygiene, 97(4), pp.1033-1042. https://doi.org/10.4269/ajtmh.17-0208.

Hamlyn-Harris, D., McAlister, T. and Dillon, P., 2019. Water Harvesting Potential of WSUD Approaches. In Approaches to Water Sensitive Urban Design (pp. 177-208). Woodhead Publishing. https://doi.org/10.1016/B978-0-12-812843-5.00009-5.

Hoekstra, A.Y. and Chapagain, A.K., 2006. Water footprints of nations: water use by people as a function of their consumption pattern. In Integrated assessment of water resources and global change (pp. 35-48). Springer, Dordrecht. Netherland.

Hoekstra, A.Y. and Mekonnen, M.M., 2012. The water footprint of humanity. Proceedings of the national academy of sciences, 109(9), pp.3232-3237. https://doi.org/10.1073/pnas.1109936109.

Hoekstra, A.Y., 2013. The water footprint of modern consumer society. Routledge. London, United Kingdom.

Hoff, A., Andersson, H., Christiansen, M., Hasle, G. and Løkketangen, A., 2010. Industrial aspects and literature survey: Fleet composition and routing. Computers \& Operations Research, 37(12), pp.2041-2061. https://doi.org/10.1016/j.cor.2010.03.015.

Hove, J., D'Ambruoso, L., Mabetha, D., Van Der Merwe, M., Byass, P., Kahn, K., Khosa, S., Witter, S. and Twine, R., 2019. 'Water is life': developing community participation for clean water in rural South Africa. BMJ Global Health, 4(3), p.e001377. http://dx.doi.org/10.1136/bmjgh-2018-001377.

IEA (international Energy Agency), 2016. Electricity Consumption. International Engineering Agency, Paris, France. See: https://www.iea.org/statistics/electricity/ (accessed 12/05/2019).

Insch, A. and Florek, M. (2008), "A great place to live, work and play: Conceptualising place satisfaction in the case of a city's residents", Journal of Place Management and Development, Vol. 1 No. 2, pp. 138-149. https://doi.org/10.1108/17538330810889970.

Insch, A., 2010. Managing residents' satisfaction with city life: Application of ImportanceSatisfaction analysis. Journal of Town \& City Management, 1(2). Pp 164 - 174. 
IPCC (Intergovernmental Panel on Climate Change), 2013. Climate Change 2013: The Physical Science Basis, Working Group I Contribution to IPCC $5^{\text {th }}$ Assessment Report.

Intergovernmental Panel on Climate Change. Geneva, Switzerland. See: http://www.esc.nsw.gov.au/development-and-planning/considerations/coastal-andflooding-considerations/coastal-projects/sea-level-rise/sea-level-rise-forum-2014/DrJohnChurch-CSIRO.pdf (accessed 11/05/2019).

James, T. (2012). Floating cities [cruise ships]. Engineering \& Technology, 7(3), 34-37. https://doi.org/10.1049/et.2012.0304.

Jenny, J.P., Francus, P., Normandeau, A., Lapointe, F., Perga, M.E., Ojala, A., Schimmelmann, A. and Zolitschka, B., 2016. Global spread of hypoxia in freshwater ecosystems during the last three centuries is caused by rising local human pressure. Global Change Biology, 22(4), pp.1481-1489. https://doi.org/10.1111/gcb.13193.

Jha, M.K., Ogallo, H.G. and Owolabi, O., 2014. A quantitative analysis of sustainability and green transportation initiatives in highway design and maintenance. Procedia-Social and Behavioral Sciences, 111, pp.1185-1194.https://doi.org/10.1016/j.sbspro.2014.01.153.

Kahn, H.D. and Stralka, K., 2009. Estimated daily average per capita water ingestion by child and adult age categories based on USDA's 1994-1996 and 1998 continuing survey of food intakes by individuals. Journal of Exposure Science and Environmental Epidemiology, 19(4), p.396.

Kaminski, S., Lawrence, A. and Trujillo, D., 2016. Structural use of bamboo: Part 1: Introduction to bamboo. The structural engineer, 94(8), pp.40-43.

Karissa, P.T., Sukardi, S.B.P., Gustaf, N., Mamangkey, F. and Taylor, J.J.U., 2012. Utilization of Low-Voltage Electricity to Stimulate Cultivation of Pearl Oysters Pinctada maxima (Jameson). Innovative Methods of Marine Ecosystem Restoration, p.131.

Kaza, S., Yao, L., Bhada-Tata, P. and Van Woerden, F., 2018. What a waste 2.0: a global snapshot of solid waste management to 2050. World Bank Publications. Urban Development. Washington, DC: World Bank. See: https://openknowledge.worldbank.org/handle/10986/30317 (accessed 13/05/2019).

Keiser, D.A. and Shapiro, J.S., 2018. Consequences of the Clean Water Act and the demand for water quality. The Quarterly Journal of Economics, 134(1), pp.349-396. https://doi.org/10.1093/qje/qjy019.

Kibert, C.J., 2016. Sustainable construction: green building design and delivery. John Wiley \& Sons, New Jersey, United States.

Kirimtat, A., Krejcar, O., Kertesz, A. and Tasgetiren, M.F., 2020. Future Trends and Current State of Smart City Concepts: A Survey. IEEE Access, 8, pp.86448-86467. https://doi.org/10.1109/ACCESS.2020.2992441.

Kosaka, Y., 2016. Scallop fisheries and aquaculture in Japan. In Developments in Aquaculture and Fisheries Science (Vol. 40, pp. 891-936). Elsevier.

Kotler, P., Armstrong, G., Saunders, J. and Wong, V., 1993. Haider, DH; Rein, I. Marketing Places: Attracting Investment, Industry and Tourism to cities, states and nations. The Free Press, New York: United States. 
Kumar, V., Shrivastava, R.L. and Untawale, S.P., 2015. Solar energy: review of potential green $\&$ clean energy for coastal and offshore applications. Aquatic Procedia, 4, pp.473-480. https://doi.org/10.1016/j.aqpro.2015.02.062.

Lagerkvist, A. and Dahlén, L., 2019. Solid Waste Generation and Characterization. Recovery of Materials and Energy from Urban Wastes: A Volume in the Encyclopedia of Sustainability Science and Technology, Second Edition, pp.7-20. Springer, New York, United States. https://doi.org/10.1007/978-1-4939-7850-2_110.

Lak, A., Ramezani, M. and Aghamolaei, R. (2019), "Reviving the lost spaces under urban highways and bridges: an empirical study", Journal of Place Management and Development, Vol. 12 No. 4, pp. 469-484. https://doi.org/10.1108/JPMD-12-2018-0101

Lakkad, S.C. and Patel, J.M., 1981. Mechanical properties of bamboo, a natural composite. Fibre science and technology, 14(4), pp.319-322. https://doi.org/10.1016/0015-0568(81)90023$\underline{3}$.

Lazzarini, G.A., Visschers, V.H. and Siegrist, M., 2017. Our own country is best: Factors influencing consumers' sustainability perceptions of plant-based foods. Food quality and preference, 60, pp.165-177.

Lewandowska, A. and Szymańska, D., 2019. Municipal waste recycling in big cities in Poland in the context of ecologisation. Bulletin of Geography. Socio-economic Series, 43(43), pp.131-141. http://dx.doi.org/10.1515/18103.

Li, F., Cai, B., Ye, Z., Wang, Z., Zhang, W., Zhou, P. and Chen, J., 2019. Changing patterns and determinants of transportation carbon emissions in Chinese cities. Energy, 174, pp.562575. https://doi.org/10.1016/j.energy.2019.02.179.

Liang, X. (2017). Emerging Power Quality Challenges Due to Integration of Renewable Energy Sources. IEEE Transactions on Industry Applications, 53(2), 855-866. https://doi.org/10.1109/tia.2016.2626253.

Lin, Y.H., Chih Lin, Y. and Tan, H.S., 2019. Design and functions of floating architecture-a review. Marine Georesources \& Geotechnology, 37(7), pp.880-889. https://doi.org/10.1080/1064119X.2018.1503761.

Lund, J.W. and Boyd, T.L., 2016. Direct utilization of geothermal energy 2015 worldwide review. Geothermics, 60, pp.66-93. https://doi.org/10.1016/j.geothermics.2015.11.004.

Mariutti, F. (2017), "The placement of country reputation towards place management", Journal of Place Management and Development, Vol. 10 No. 3, pp. 240-253. https://doi.org/10.1108/JPMD-10-2016-0067.

Martin, D.W. and Evans, R.R., Indoor Farms Of America LLC, 2018. Vertical Aeroponic Plant Growing Enclosure. U.S. Patent Application 15/707,574. See: https://patents.google.com/patent/US9374953 (accessed 18/05/2019).

Martins, V.W.B., Anholon, R., Luiz, O. and Quelhas, G., 2019. Sustainable Transportation Methods. W. Leal Filho (ed.), Encyclopedia of Sustainability in Higher Education. Springer Nature Switzerland AG 2019. https://doi.org/10.1007/978-3-319-63951-2_192$\underline{1}$. 
Masuda, K., Maeda, H., Takamura, H. and Bessho, M., 1999, January. Research on prediction method for time history elastic response of very large floating structure by sea shock loads. In The Ninth International Offshore and Polar Engineering Conference. International Society of Offshore and Polar Engineers. ISBN 1-880653-39-7 (Set); ISBN 1-880653-40-0 (Vol. I); ISSN 1098-6189 (Set). Pp. 792-799.

Mathiesen, B. V., Lund, H., Connolly, D., Wenzel, H., Østergaard, P. A., Möller, B., ... Hvelplund, F. K. (2015). Smart Energy Systems for coherent 100\% renewable energy and transport solutions. Applied Energy, 145, 139-154. https://doi.org/10.1016/j.apenergy.2015.01.075.

Mehar S, Zeadally S, Rémy G, Senouci SM (2014) Sustainable transportation management system for a fleet of electric vehicles. IEEE Trans Intell Transp Syst 16:1401-1414. https://doi.org/10.1109/TITS.2014.2367099.

Mekonnen, M.M. and Hoekstra, A.Y. (2011) National water footprint accounts: the green, blue and grey water footprint of production and consumption, Value of Water Research Report Series No. 50, UNESCO-IHE, Delft, the Netherlands. See: https://waterfootprint.org/media/downloads/Report50-NationalWaterFootprints-Vol1.pdf (accessed 12/05/2019).

Mengi, O. and Guaralda, M. (2020), "Multidimensional management framework for creative places", Journal of Place Management and Development, Vol. ahead-of-print No. aheadof-print. https://doi.org/10.1108/JPMD-02-2019-0010.

Menouar, H., Guvenc, I., Akkaya, K., Uluagac, A. S., Kadri, A., \& Tuncer, A. (2017). UAVEnabled Intelligent Transportation Systems for the Smart City: Applications and Challenges. IEEE Communications Magazine, 55(3), 22-28. https://doi.org/10.1109/mcom.2017.1600238cm.

Miles, M., 2019. Cities and Literature. Routledge. London, United Kingdom.

Mohamed, N., Al-Jaroodi, J., Jawhar, I., Idries, A. and Mohammed, F., 2018. Unmanned aerial vehicles applications in future smart cities. Technological Forecasting and Social Change. https://doi.org/10.1016/j.techfore.2018.05.004.

Moher D, Liberati A, Tetzlaff J, Altman DG, Prisma Group. Preferred reporting items for systematic reviews and meta-analyses: the PRISMA statement. PLoS medicine. $2009 \mathrm{Jul}$ 21;6(7):e1000097. https://doi.org/10.7326/0003-4819-151-4-200908180-00135.

MOMA (The Museum of Modern Art), 2019. Tetrahedron City Project, Yomiuriland, Japan (Aerial perspective). The Museum of Modern Art, New York, United States. See: https://www.moma.org/collection/works/863 (accessed 12/05/2019).

Nagpal, S., Mueller, C., Aijazi, A. and Reinhart, C.F., 2019. A methodology for auto-calibrating urban building energy models using surrogate modeling techniques. Journal of Building Performance Simulation, 12(1), pp.1-16. https://doi.org/10.1080/19401493.2018.1457722.

Nakajima, T. and Umeyama, M., 2009, December. Floating Cities as a solution to the escalating sea level rise in lower-lying land areas. In Proceedings of the Regional Conference Environment \& Earth Resources, Kuantan, Malaysia (Vol. 78, p. 261269). 
Nakayama, T., Watanabe, M., Tanji, K. and Morioka, T., 2007. Effect of underground urban structures on eutrophic coastal environment. Science of the Total Environment, 373(1), pp.270-288. https://doi.org/10.1016/j.scitotenv.2006.11.033.

National Geographic, 2011. What the World Eats. National Geographic. Washington, D.C., United States. See: https://www.nationalgeographic.com/what-the-world-eats/ (accessed 13/05/2019).

NLBS (National Library Board Singapore), 2017. Land From Sand: Singapore's Reclamation Story. National Library Board Singapore. See: http://www.nlb.gov.sg/biblioasia/2017/04/04/land-from-sand-singapores-reclamationstory/ (accessed 11/05/2019).

O'Keefe, S. J. D. (2019). Plant-based foods and the microbiome in the preservation of health and prevention of disease. The American Journal of Clinical Nutrition. https://doi.org/10.1093/ajcn/nqz127.

OCEANIX, 2019. Net-Zero Energy. Oceanix. New York, United States. See: https://oceanix.org/net-zero-energy/ (accessed 12/05/2019).

Ocetkiewicz, I., Tomaszewska, B. and Mróz, A., 2017. Renewable energy in education for sustainable development. The Polish experience. Renewable and Sustainable Energy Reviews, 80, pp.92-97. https://doi.org/10.1016/j.rser.2017.05.144.

OECD (Organization for Economic Co-operation and Development), 2012. OECD Environmental Outlook to 2050, The Consequences of Inaction. Paris, France. See: http://www.naturvardsverket.se/upload/miljoarbete-i-samhallet/internationelltmiljoarbete/multilateralt/oecd/outolook-2050-oecd.pdf (accessed 11/05/2019).

Otoma, S., Hoang, H., Hong, H., Miyazaki, I., \& Diaz, R. (2013) A survey on municipal solid waste and residents' awareness in Da Nang city, Vietnam. Journal of Material Cycles and Waste Management, 15(2), 187-194. https://doi.org/10.1007/s10163-012-0109-2.

Patel, A., 2019. Geotechnical Investigations and Improvement of Ground Conditions. Woodhead Publishing. Cambridge, United Kingdom.

Petering, M.E., 2011. Decision support for yard capacity, fleet composition, truck substitutability, and scalability issues at seaport container terminals. Transportation Research Part E: Logistics and Transportation Review, 47(1), pp.85-103. https://doi.org/10.1016/j.tre.2010.07.007.

Piyapong, J., Riruengrong, R., Wipawee, I., Siriphan, N. and Passanan, A. (2019), "Empirical evidence of the roles of public spaces and public activities in the promotion of community relations and sense of place in a coastal community", Journal of Place Management and Development, Vol. 12 No. 4, pp. 485-507. https://doi.org/10.1108/JPMD-09-2018-0065.

Postel, S.L., 2000. Entering an era of water scarcity: the challenges ahead. Ecological applications, 10(4), pp.941-948. https://doi.org/10.1890/10510761(2000)010[0941:eaeows]2.0.co;2. 
Qi, F., Zhu, X., Mang, G., Kadoch, M. and Li, W., 2019. UAV Network and IoT in the Sky for Future Smart Cities. IEEE Network, 33(2), pp.96-101. https://doi.org/10.1109/MNET.2019.1800250.

Rassia, S.T. and Pardalos, P.M., 2014. Cities for smart environmental and energy futures. Impacts on Architecture and Technology, Springer-Verlag Berlin Heidelberg. pp.978-3. https://doi.org/10.1007/978-3-642-37661-0.

Ray B., Shaw R. (2019) Defining Urban Water Insecurity: Concepts and Relevance. In: Ray B., Shaw R. (eds) Urban Drought. Disaster Risk Reduction (Methods, Approaches and Practices). Springer, Singapore. https://doi.org/10.1007/978-981-10-8947-3_1.

Ridoutt, B. G., \& Pfister, S. (2010). Reducing humanity's water footprint. Environmental Science \& Technology, 44(16), 6019-6021. https://doi.org/10.1021/es101907z.

Ritchie, H. and Roser, M. 2019. "Water Use and Sanitation". Published online at OurWorldInData.org. See: https://ourworldindata.org/water-use-sanitation (accessed 12/05/2019).

Rizal, M. and Faizal, A., 2018. The escalation of coral growth by biorock technology applied in Sabang marine ecotourism. Aquaculture, Aquarium, Conservation \& Legislation, 11(5), pp.1633-1647.

Saeed, M.O., Hassan, M.N. and Mujeebu, M.A., 2009. Assessment of municipal solid waste generation and recyclable materials potential in Kuala Lumpur, Malaysia. Waste management, 29(7), pp.2209-2213.

Salehi M, Jalalian M, Siar MMV (2017) Green transportation scheduling with speed control: trade-off between total transportation cost and carbon emission. Comput Ind Eng 113:392-404. https://doi.org/10.1016/j.cie.2017.09.020.

SAM (Space and Matter), 2019. Schoonschip. Space and Matter, Amsterdam, The Netherlands See: http://www.spaceandmatter.nl/schoonschip\# (accessed 12/05/2019).

Seasteading Institute, 2020. Active Projects. Seasteading Institute, San Francisco, CA, United States. See: https://www.seasteading.org/active-projects/ (accessed 18/08/2020).

Shafaghat, A., Manteghi, G., Keyvanfar, A., Lamit, H.B., Saito, K. and Ossen, D.R., 2016. Street geometry factors influence urban microclimate in tropical coastal cities: A review. Environmental and Climate Technologies, 17(1), pp.61-75. https://doi.org/10.1515/rtuect2016-0006.

Shi, L., Wu, K.J. and Tseng, M.L., 2017. Improving corporate sustainable development by using an interdependent closed-loop hierarchical structure. Resources, Conservation and Recycling, 119, pp.24-35. https://doi.org/10.1016/j.resconrec.2016.08.014.

Shih, T.-H., \& Xitao Fan. (2008). Comparing Response Rates from Web and Mail Surveys: A Meta-Analysis. Field Methods, 20(3), 249-271. https://doi.org/10.1177/1525822x08317085.

Sroufe, R., 2017. Integration and organizational change towards sustainability. Journal of Cleaner Production, 162, pp.315-329. https://doi.org/10.1016/j.jclepro.2017.05.180. 
Suzuki, H. (2005). Overview of Megafloat: Concept, design criteria, analysis, and design. Marine Structures, 18(2), 111-132. https://doi.org/10.1016/j.marstruc.2005.07.006.

Talip, A.R.A., Draman, N.Z., Martin, J., Ismail, H.B., Hasan, A.C. and Jamal, M.H., 2019. Malaysian Household Perception Towards Recycling and Waste Generation: A Case Study at Northern Region Housing Area. In Proceedings of the Regional Conference on Science, Technology and Social Sciences (RCSTSS 2016) (pp. 577-585). Springer, Singapore.

Townsend, A.M., 2013. Smart cities: Big data, civic hackers, and the quest for a new utopia. WW Norton \& Company. New York, United States.

Uihlein, A. and Magagna, D., 2016. Wave and tidal current energy-A review of the current state of research beyond technology. Renewable and Sustainable Energy Reviews, 58, pp.1070-1081. https://doi.org/10.1016/j.rser.2015.12.284.

Umar, T. and Egbu, C., 2018. Perceptions on safety climate: a case study in the Omani construction industry. Proceedings of the ICE-Management, Procurement and Law, 171(6), pp.251-263. https://doi.org/10.1680/jmapl.18.00001.

Umar, T. and Egbu, C., 2019. Global commitment towards sustainable energy. Proceedings of the Institution of Civil Engineers-Engineering Sustainability. Volume 172 Issue 6, September 2019, pp. 315-323. In Focus: SEB16. Thomas Telford Ltd. https://doi.org/10.1680/jensu.17.00059.

Umar, T. and Egbu, C., 2020. Heat stress, a hidden cause of accidents in construction. Proceedings of the Institution of Civil Engineers-Municipal Engineer (Vol. 173, No. 1, pp. 49-60). Thomas Telford Ltd. http://dx.doi.org/10.1680/jmuen.18.00004.

Umar, T. and Wamuziri, S., 2016. Conventional, wind and solar energy resources in Oman. Proceedings of the Institution of Civil Engineers-Energy, 169(4), pp.143-147. https://doi.org/10.1680/jener.16.00011.

Umar, T., 2017-a. Cost of accidents in the construction industry of Oman. Proceedings of the Institution of Civil Engineers-Municipal Engineer (Vol. 170, No. 2, pp. 68-73). Thomas Telford Ltd. http://dx.doi.org/10.1680/jmuen.16.00032.

Umar, T., 2017-b. Rooftop solar photovoltaic energy: a case study of India. Nanomaterials and Energy, 6(1), pp.17-22. https://doi.org/10.1680/jnaen.16.00002.

Umar, T., 2018-a. Geothermal energy resources in Oman. Proceedings of the Institution of Civil Engineers-Energy, 171(1), pp.37-43. https://doi.org/10.1680/jener.17.00001.

Umar, T., 2018-b. Towards a sustainable energy: the potential of biomass for electricity generation in Oman. Proceedings of the Institution of Civil Engineers-Engineering Sustainability (Vol. 171, No. 7, pp. 329-333). Thomas Telford Ltd. https://doi.org/10.1680/jensu.17.00001.

Umar, T., 2020. Frameworks for Reducing Greenhouse Gas (GHG) Emissions from Municipal Solid Waste in Oman. Management of Environmental Quality, Emerald Publishing. Pp. 1-49. https://doi.org/10.1108/MEQ-11-2019-0231. 
Umar, T., Egbu, C. and Saidani, M., 2019-c. A Modified Method for Los Angeles Abrasion Test. Iranian Journal of Science and Technology, Transactions of Civil Engineering, pp.1-7. https://doi.org/10.1007/s40996-019-00268-w.

Umar, T., Egbu, C., Honnurvali, M.S., Saidani, M. and Al-Mutairi, M., 2019-b. An assessment of health profile and body pain among construction workers. Proceedings of the Institution of Civil Engineers-Municipal Engineer (pp. 1-12). Thomas Telford Ltd. https://doi.org/10.1680/jmuen.18.00019.

Umar, T., Egbu, C., Ofori, G., Honnurvali, M.S., Saidani, M. and Opoku, A., 2020-b. Challenges towards renewable energy: an exploratory study from the Arabian Gulf region. Proceedings of the Institution of Civil Engineers-Energy, Volume 173 Issue 2, pp. 68-80. https://doi.org/10.1680/jener.19.00034.

Umar, T., Egbu, C., Ofori, G., Honnurvali, M.S., Saidani, M., and Opoku., A., 2019-a. Exploring Safety Climate in Construction. International Journal of Applied Management Science, Inderscience Publisher. https://doi.org/ 10.1504/IJAMS.2019.253274.

Umar, T., Egbu, C., Ofori, G., Honnurvali, M.S., Saidani, M., Shibani, A., Opoku, A., Gupta, N. and Goh, K., 2020-a. UAE's Commitment Towards UN Sustainable Development Goals. Proceedings of the Institution of Civil Engineers-Engineering Sustainability (pp. 1-18). Thomas Telford Ltd. https://doi.org/10.1680/jensu.19.00036.

UN-Habitat, 2019. Climate Change. UN-Habitat, United Nation, New York United States See: https://unhabitat.org/urban-themes/climate-change/ (accessed 12/05/2019).

UN-SDGs (United Nations Sustainable Development Goals), 2015. About the Sustainable Development Goals. United Nations, New York, United States. See: https://www.un.org/sustainabledevelopment/sustainable-development-goals/ (accessed 23/04/2019).

UN-SFC (United Nations-Sustainable Floating Cities), 2019. Sustainable Floating Cities Can Offer Solutions to Climate Change Threats Facing Urban Areas, Deputy SecretaryGeneral Tells First High-Level Meeting. United Nations, New York, United States. See: https://www.un.org/press/en/2019/dsgsm1269.doc.htm (accessed 11/05/2019).

Uriarte, I., Astorga, M., Navarro, J. C., Viana, M. T., Rosas, C., Molinet, C., ... Farías, A. (2018). Early life stage bottlenecks of carnivorous molluscs under captivity: a challenge for their farming and contribution to seafood production. Reviews in Aquaculture. https://doi.org/10.1111/raq.12240

Van der Valk, A.J.J., 2016. Food Planning and Landscape in the'Gastropolis' of New York. In Sixth AESOP Conference on Sustainable Food Planning: Finding Spaces for Productive Cities (pp. 353-380).

Van Tuijl, E., Hospers, G.J. and Van Den Berg, L., 2018. Opportunities and challenges of urban agriculture for sustainable city development. European Spatial Research and Policy, 25(2), pp.5-22. https://content.sciendo.com/view/journals/esrp/25/2/esrp.25.issue-2.xml.

Van-Vuuren, D.P., Stehfest, E., Gernaat, D.E., Berg, M., Bijl, D.L., Boer, H.S., Daioglou, V., Doelman, J.C., Edelenbosch, O.Y., Harmsen, M. and Hof, A.F., 2018. Alternative pathways to the $1.5 \mathrm{C}$ target reduce the need for negative emission technologies. Nature Climate Change, 8(5), p.391. https://www.nature.com/articles/s41558-018-0119-8. 
Visual Capitalist, 2016. Energy Archived. Visual Capitalist. New York, United States. See: https://www.visualcapitalist.com/category/energy/ (accessed 12/05/2019).

Wang, J., O'Donnell, J. and Brandt, A.R., 2017. Potential solar energy use in the global petroleum sector. Energy, 118, pp.884-892. https://doi.org/10.1016/j.energy.2016.10.107.

Water Footprint Network, 2019. National water footprint explorer. Water Footprint Network. Enschede, The Netherlands. See: http://www.waterfootprintassessmenttool.org/nationalexplorer/ (accessed 12/05/2019).

Wells, L., Perez, F., Hibbert, M., Clerveaux, L., Johnson, J. and Goreau, T.J., 2010. Effect of severe hurricanes on Biorock coral reef restoration projects in Grand Turk, Turks and Caicos Islands. Revista de biología tropical, pp.141-149. https://doi.org/10.15517/rbt.v58i0.20065.

WUP (World Urbanization Prospects), 2018. World Urbanization Prospects: The 2018 Revision. Office of the Director, Population Division, United Nations. New York, United States. https://population.un.org/wup/Publications/Files/WUP2018-KeyFacts.pdf (accessed 11/05/2019).

WWAP (World Water Development Report), 2003. The United Nations World Water Development Report 1: Water for people, water for life, World Water Assessment Programme, UNESCO Publishing, Paris / Berghahn Books, New York.

WWAP (World Water Development Report), 2006. The United Nations World Water Development Report 2: Water a shared responsibility, World Water Assessment Programme, UNESCO Publishing, Paris / Berghahn Books, New York.

WWAP (World Water Development Report), 2009. The United Nations World Water Development Report 3: Water in a changing world, World Water Assessment Programme, UNESCO Publishing, Paris / Earthscan, London.

Yan, X., Zhang, H. and Wu, C., 2012, October. Research and development of intelligent transportation systems. In 2012 11th International Symposium on Distributed Computing and Applications to Business, Engineering \& Science (pp. 321-327). IEEE. https://doi.org/10.1109/DCABES.2012.107.

Yeo, J., Oh, J.I., Cheung, H.H., Lee, P.K. and An, A.K., 2019. Smart Food Waste Recycling Bin (S-FRB) to turn food waste into green energy resources. Journal of environmental management, 234, pp.290-296. https://doi.org/10.1016/j.jenvman.2018.12.088.

Zafar, S., 2018. Waste Management Outlook for the Middle East. In The Palgrave Handbook of Sustainability (pp. 159-181). Palgrave Macmillan, Cham, Basingstoke, United Kingdom.

Zeng, Y. and Zhang, R., 2017. Energy-efficient UAV communication with trajectory optimization. IEEE Transactions on Wireless Communications, 16(6), pp.3747-3760. https://doi.org/10.1109/twc.2017.2688328

Zenker S, Petersen S, Aholt A. The Citizen Satisfaction Index (CSI): Evidence for a four basic factor model in a German sample. Cities. 2013 Apr 1;31:156-64. http://dx.doi.org/10.1016/j.cities.2012.02.006. 
Zenker, S., \& Rütter, N. (2014). Is satisfaction the key? The role of citizen satisfaction, place attachment and place brand attitude on positive citizenship behavior. Cities, 38, 11-17. https://doi.org/10.1016/j.cities.2013.12.009.

Zhou, Y. and Zhao, J., 2016. Advances and challenges in underground space use in Singapore. Geotechnical Engineering Journal of the SEAGS and AGSSEA, 47(3), pp.85-95. http://seags.ait.asia/journals/2016/47-3-september/19544-advances-and-challenges-inunderground-space-use-in-singapore/.

ZWDG (Zero Waste Design Guidelines), 2019. Design Strategies and Case Studies for a ZeroWaste City. Zero Waste Design Guidelines, The Center for Architecture, New York, United States. See: https://www.zerowastedesign.org/ (accessed 13/05/2019).

Zyadin, A., Halder, P., Kähkönen, T. and Puhakka, A., 2014. Challenges to renewable energy: A bulletin of perceptions from international academic arena. Renewable energy, 69, pp.8288. https://doi.org/10.1016/j.renene.2014.03.029. 